\title{
PROCESSOS, CONDICIONANTES E BASES SOCIAIS DA ESPECIALIZAÇÃO POLÍTICA NO RIO GRANDE DO SUL E NO MARANHÃO
}

\author{
Igor Gastal Grill
}

\begin{abstract}
RESUMO
No artigo são examinados os processos de especialização política, as carreiras e os perfis de deputados federais (1945-2006) em dois estados brasileiros (Rio Grande do Sul e Maranhão), identificando as vinculações entre profissionalização política e hierarquização social. São cotejadas as combinações entre bases sociais, trajetórias e concepções de política que apontam para modalidades diferenciadas de afirmação e reprodução políticas. A partir disto, são comparadas as dinâmicas de diversificação social da "elite política" nos dois estados, os condicionantes para ascensão política, as estratégias de reconversão de bases sociais em bases eleitorais e as redefinições dos mecanismos de legitimação dos papéis políticos ao longo do tempo e em cada configuração regional. As fontes privilegiadas na pesquisa foram repertórios biográficos, memórias, biografias e entrevistas em profundidade.
\end{abstract}

PALAVRAS-CHAVE: elites; especialização política; recrutamento; carreiras.

\section{INTRODUÇÃO}

O foco da pesquisa apresentada neste artigo está centrado no exame dos condicionantes sociais de afirmação e das modalidades de constituição de especialistas da atividade política em dois estados brasileiros: Rio Grande do Sul e Maranhão. Para tanto, foram analisados os perfis, as carreiras políticas e as estratégias de apresentação das origens sociais e da atuação política de deputados federais eleitos entre 1945 e 2006.

A comparação entre duas configurações ${ }^{1}$ regionais mostrou-se um procedimento importante de investigação. A forma como a "política local” é descrita em cada contexto traduz fatores de diferenciação; porém, ao explorar as dinâmicas mais detidamente, é possível encontrar aproximações de padrões e de itinerários, assim como identificar contrastes em dimensões da "vida política" ainda não examinadas de maneira detalhada.

1 A noção de "configuração" utilizada aqui se inspira nas formulações de Elias (1999) e Sawicki (1997). Para Elias (1999, p. 142) a noção comporta ações e reações dos jogadores, tensões e interdependências entrelaçadas responsáveis pelas modificações históricas e pelos arranjos societais. Sawicki (1997, p. 37) definiu a configuração como o espaço onde as relações de força entre grupos sociais tomam uma forma singular, modelando e retraduzindo as mudanças de todas as ordens que a afetam.
No caso do Rio Grande do Sul, a bibliografia "local" descreve a "política gaúcha" ao longo do século XX como marcada por uma "secular bipolarização” (TRINDADE \& NOLL, 1991; CÁNEPA, 1999, entre outros) com ênfase nos modelos de organizações partidárias e nos alinhamentos ideológicos afirmados em "ismos" (“castilhismo", "borgismo”, "positivismo", "federalismo", "liberalismo”, "trabalhismo”, "petismo" etc.). Maior "politização do eleitorado" e sua identificação com os partidos, bem como definição "programática” e experiências ímpares de formações partidárias são elementos grifados para fixar a "especificidade regional". Além disso, no bojo das disputas entre "forças políticas", ocorreu o ingresso de segmentos sociais diversificados na arena política: os estancieiros do Norte do estado, que se opuseram às "elites" da "campanha" nas primeiras décadas do século XX (PINTO, 1986); as camadas "médias" e "populares" (em siglas como a AIB (Ação Integralista Brasileira) e a ANL (Aliança Nacional Libertadora)); a absorção de “elites” ligadas à imigração (descendentes de imigrantes alemães, sírios, libaneses e italianos) a partir de 1945 (TRINDADE \& NOLL, 1991, p. 12-24); os agentes vinculados à liderança junto aos sindicatos (rurais, de ferroviários, de comerciários), à Igreja Católica, ao cooperativismo (CORADINI, 1998a); por fim, nas últimas déca- 
das, os "setores sindicais" e quadros oriundos do movimento estudantil, do Movimento dos Trabalhadores Rurais Sem-Terra (MST) e dos partidos de “esquerda” (REIS, 2007).

A partir dos alinhamentos partidários e da diversificação social assinalados para o caso do Rio Grande do Sul é possível perceber processos de "sucessão" controlados por "famílias de políticos" e por lideranças de facções estaduais que definem uma dinâmica de seleção prévia (em relação à escolha dos eleitores) dos futuros ocupantes de cargos eletivos. A despeito da singularidade proclamada, têm-se práticas orquestradas - comumente tipificadas como "tradicionais" - de controle pela "elite política gaúcha" do ingresso e da ascensão política, bem como de reprodução de práticas e modalidades de atendimento às bases por parte dos agentes, "famílias" e segmentos que ascendem politicamente ao longo do século XX (GRILL, 2003).

No caso do Maranhão, os diferentes autores que se dedicam ao estudo das "elites políticas" apontam para o caráter “conservador” e "oligárquico” da política no estado, mas ressaltam igualmente o ingresso de alguns novos perfis no cenário eleitoral (GONÇALVES, 2000; 2004; BORGES, 2004; COSTA, 2006; REIS, 2007). Não raro, nessa literatura é sublinhado o surgimento de novos repertórios de atuação política e de trunfos como o "gosto literário", a preocupação com "problemas sociais e econômicos", a idéia de "projeto de desenvolvimento para o estado" sob "bases científicas", a "retórica modernizadora" e, conseqüentemente, a afirmação de bacharéis, jornalistas, economistas etc. na ascensão das chamadas "oposições coligadas"2 nas décadas de 1950 e 1960. Nesse período, marcado pelos embates entre "vitorinistas" e "oposicionistas", ocorrera a absorção, pelas duas facções que polarizavam a política estadual, de "descendentes de imigrantes libaneses" ligados às atividades comerciais (BUZAR, 1998; 2001). O ingresso de novos segmentos sociais e a edificação de móbiles de identificação também são evidenciados no final da década de 1970 e início da década de 1980 . No período posterior ao regime militar, o movimento

2 "Frente" que reunia os políticos que faziam oposição à facção política comandada por Vitorino Freire e que passou a ser denominada de “vitorinismo" (cf. GONÇALVES, 2000; COSTA, 2006). estudantil, as organizações de base da Igreja Católica, a Sociedade Maranhense dos Direitos Humanos e o sindicalismo rural afirmaram-se como "viveiros" de lideranças políticas, entre outros meios de inscrição (BORGES, 2004).

Na esteira dos trabalhos acima citados é factível refletir sobre a persistência de práticas e lógicas políticas classificadas na própria produção "local” como "patrimoniais”, “oligárquicas”, de "apelo ao centro" (COSTA, 2006; REIS, 2007) ou que enfatizam a legitimação pelo princípio “dinástico”, da "descendência" e dos "laços pessoais" (GONÇALVES, 2000; 2006) ou ainda que realçam o caráter "personalista”, “assistencialista” e a centralidade da mediação "entre as várias esferas de poder e controle de recursos" (BORGES, 2004). Os autores mencionados chamam a atenção para semelhanças e continuidades em processos ou momentos que aparentam rupturas e substituição de forças políticas.

Nesta pesquisa, objetivamos contemplar, nas duas configurações, três dimensões sistematizadas por Michel Offerlé (1999) para o estudo dos processos de especialização política que estão ligadas às agendas de estudos descritas acima. Em primeiro lugar, procuramos captar a influência do cabedal na entrada e no desempenho das carreiras políticas, utilizando macrofatores explicativos das formas de recrutamento político (origem social, profissão, escolarização etc.), bem como ponderar sobre os micromecanismos que processam tais elementos a partir das dinâmicas sociais, eleitorais e escolares que são específicas em cada contexto, sem deixar de acentuar a relevância dos usos das origens sociais nas auto-apresentações (idem, p. 27). Em segundo lugar, consideramos o longo movimento que gera a imposição da especialização na política, isto é, em que se exige dos agentes que se tornem "profissionais", consagrando a maior parte do seu tempo às atividades políticas, desligando-se de uma profissão anterior ou mesmo não chegando a exercê-la, conseguindo monopolizar a ocupação de cargos e o direito às candidaturas e conquistando antiguidade e continuidade no interior do espaço político (idem, p. 15). Por fim, é indispensável não nos descolarmos da idéia de que o processo de profissionalização política comporta a lógica de denegação identitária, que faz que os políticos, "apesar de consagrarem todo tempo a essa atividade, como profissionais, reivindiquem o seu exercício como vocação [...]” (idem, p. 17). 
Levando em conta essas dimensões, privilegiamos as seguintes fontes: o Dicionário históricobiográfico do Brasil pós-30, do Centro de Pesquisa e Documentação da Fundação Getúlio Vargas (ABREU et alii, 2001), que possibilitou reunir informações sobre os perfis (profissão, grau de escolarização, título superior obtido e instituição em que o obteve) e as carreiras políticas (cargo e idade de ingresso na ocupação de cargos públicos e eletivos, tempo de carreira em cargos públicos e eletivos, carreira eletiva prévia à ocupação do mandato de Deputado Federal e número de candidaturas) de 200 deputados gaúchos e 100 deputados "maranhenses". Foram também analisadas memórias, biografias e genealogias concernentes aos deputados federais e a suas "famílias”, assim como um conjunto de 35 entrevistas realizadas com deputados ou com membros das suas "famílias” (24 com agentes provenientes do Rio Grande do Sul e 11 do Maranhão). A partir da análise desse material foi possível relacionar: a) as origens sociais, b) os percursos escolares, profissionais e políticos, c) as estratégias de consagração dos deputados, como também dos seus "ascendentes" e de outros membros da "família" que igualmente ocuparam postos eletivos.

\section{PERFIS: PROFISSÃO E ESCOLARIZAÇÃO}

Como foi dito, os perfis dos parlamentares foram identificados mediante o exame das informações reunidas para 200 deputados federais do Rio Grande do Sul e para 100 do Maranhão, sobre ocupações exercidas, grau de escolarização, títulos escolares obtidos e instituições em que os obtiveram.

O que os dados revelam sobre a profissão prévia dos ocupantes de cargos eletivos? A questão permite explorar duas hipóteses distintas: a primeira sustenta a existência de proximidades, cumplicidades e habilidades comuns entre espaços de exercício de determinadas profissões e a esfera política (GARRAUD, 1989; DOGAN, 1999, entre outros). A segunda hipótese afirma que a escolha de determinada ocupação é condicionada por uma série de disposições e relações de origem e sua reconversão para a política depende mais de uma multiplicidade de outros recursos herdados ou adquiridos pelos agentes do que do treinamento, da formação ou do exercício profissional (WILLEMEZ, 1999; CORADINI, 2001). Antes que opostas, tais formas de tratamento são complementares e profícuas.
As características dos universos ora analisados denotam um fenômeno bastante conhecido de sobre-representação das camadas mais altas da população e sub-representação das mais baixas na política (GAXIE, 1980). Do mesmo modo, assinalam a relevância de profissionais como advogados, médicos, funcionários públicos de vários escalões (considerados tanto aqueles que passaram por concurso como aqueles indicados por meio de laços políticos), empresários (de grande e médio portes), proprietários rurais (idem), jornalistas, entre outros.

Tanto no Rio Grande do Sul como no Maranhão o conjunto das profissões exercidas ${ }^{3}$ no período que precede o ingresso na carreira eletiva (ocupação do primeiro cargo eletivo) sinaliza a importância de três fatores: 1 ) a reconversão de uma notoriedade profissional (indicada principalmente pelo número de advogados, médicos, jornalistas, professores e professores universitários); 2) o peso do patrimônio econômico e do pertencimento aos círculos que compõem as "elites econômicas” nas carreiras políticas (sugerido pela significativa presença de empresários e proprietários rurais); 3) a passagem por funções públicas (via concurso ou nomeação com base em laço político $)^{4}$ - sendo que as bases sociais derivadas da profissão não são excludentes entre si.

No entanto, é necessário apresentar as diferenças que existem entre os dois estados. Proporcionalmente, no Rio Grande do Sul há um número maior de advogados, professores e professo-

\footnotetext{
3 Optamos por considerar todas as atividades exercidas previamente à ocupação do primeiro cargo porque assim é possível observar a interdependência entre diferentes inserções sociais prévias à carreira política dos agentes. Prova disso é que a soma das profissões identificadas no conjunto da população de cada estado extrapola em muito o número de casos analisados.

4 Dogan (1999, p. 174) salientou a "afinidade evidente" entre profissões do domínio du verbe et de la plume (“do verbo e da pluma") como advocacia, jornalismo e magistério, assim como o peso dos funcionários públicos, na esfera política na caso da França. Rodrigues (2002, p. 116) destacou, a partir da bibliografia sobre diversos países, a importância de categorias como funcionários, professores, advogados, jornalistas e profissionais liberais como "fontes de abastecimento da classe política”; o principal motivo apontado é justamente que essas profissões possibilitam um tempo livre maior e/ou grande flexibilidade no horário de trabalho, além do “domínio da oratória”. Por fim, esse autor também salientou a presença de empresários nos parlamentos.
} 
res universitários, ao passo que no Maranhão predominam os empresários, os proprietários rurais e os funcionários públicos. No primeiro caso, a diversificação social no recrutamento é mais contundente, assim como é maior o peso de profissões que possibilitam a afirmação de um reconhecimento como intelectual e de uma posição de porta-voz de causas legítimas ${ }^{5}$. No segundo caso, o recrutamento é mais concentrado em termos de extração social e há uma forte recorrência de profissões relacionadas ao domínio econômico e à administração pública. Esse contraste tem correlação com os padrões de carreiras descritos na próxima seção e que demonstram, por meio dos itinerários apreendidos, que para os deputados gaúchos há uma predominância no uso da titulação e da formação profissional (associados a outros recursos) para a construção de bases eleitorais, enquanto para os deputados maranhenses constata-se a existência de uma simbiose entre o mundo empresarial e a gestão do estado, conjugada à absorção de médicos, engenheiros e advogados em cargos públicos que, posteriormente, reconvertem os recursos acumulados em bases eleitorais.

\section{QUADRO I - PROFISSÃO EXERCIDA ANTES DO} PRIMEIRO CARGO ELETIVO

\begin{tabular}{|l|c|c|}
\hline \multirow{2}{*}{ PROFISSÃO } & \multicolumn{2}{|c|}{$\begin{array}{c}\text { NÚMERO DE } \\
\text { CASOS }\end{array}$} \\
\cline { 2 - 3 } & RS & MA \\
\hline Advogados & 100 & 34 \\
Empresários (grandes e & 30 & 50 \\
médios) & & \\
Proprietários Rurais (grande & 30 & 30 \\
e médio) & & \\
Professores Universitários & 30 & 11 \\
Professores & 20 & 7 \\
Jornalistas & 15 & 7 \\
Comunicadores (rádio e TV) & 6 & - \\
Médicos & 10 & 15 \\
Dentistas & 4 & 1 \\
Alto Funcionário Público & 18 & 25 \\
Médio Funcionário Público & 14 & 30 \\
Baixo Funcionário Público & 10 & 5 \\
Metalúrgico & 3 & 1 \\
Pescador & 1 & - \\
Pequeno Agricultor & 3 & - \\
Estudante & 1 & 3 \\
\hline
\end{tabular}

FONTES: o autor, a partir de Abreu et alii (2001) e entrevistas.

5 Para um estudo detalhado sobre as estratégias de afirmação de recursos intelectuais e militantes, ver Reis (2007).
A associação de um deputado a determinada categoria profissional depende em parte do acesso aos cursos universitários e do investimento na conquista de um diploma de curso superior. Os dados explicitam a importância da titulação superior nos dois contextos, ou seja, a porcentagem de deputados com título superior somados àqueles que possuem pós-graduação supera $85 \%$ dos casos (87\% no Rio Grande do Sul e $85 \%$ no Maranhão $)^{6}$.

QUADRO 2-GRAU DE ESCOLARIZAÇÃO
\begin{tabular}{|l|c|c|c|c|}
\hline NíVEL DE & \multicolumn{3}{|c|}{ RS } & \multicolumn{3}{c|}{ MA } \\
\cline { 2 - 5 } ESCOLARIZAÇÃo & $\boldsymbol{N .}$ & $\%$ & $\mathbf{N .}$ & $\%$ \\
\hline Superior + Pós- & 28 & 14 & 21 & 21 \\
Graduação & & & & \\
Superior & 146 & 73 & 64 & 64 \\
Superior incompleto & 1 & 0,5 & 3 & 3 \\
Médio & 15 & 7,5 & 7 & 7 \\
Curso Técnico & 7 & 3,5 & 3 & 3 \\
Médio incompleto & 3 & 1,5 & 2 & 2 \\
Total & 200 & 100 & 100 & 100 \\
\hline
\end{tabular}

FONTES: o autor, a partir de Abreu et alii (2001) e entrevistas.

Porém, evidentemente ocorrem variações no que se refere aos diplomas escolhidos e às instituições de ensino freqüentadas. Apesar de nos dois estados predominarem os deputados titulados nos cursos de Direito, Medicina e Engenharia, em termos proporcionais observa-se no Rio Grande do Sul maior incidência de parlamentares formados em Direito (63,2\% contra 41,2\% no Maranhão) ${ }^{7}$ e uma diversificação maior de títulos; por outro lado, no Maranhão a freqüência é maior dos formados em Medicina (17,7\% contra 5,7\% no Rio

\footnotetext{
6 Porcentagens próximas à identificada por Rodrigues (2002, p. 99) para o conjunto dos deputados federais que compõem a $51^{\text {a }}$ Legislatura. Segundo o autor, um total de $82 \%$ dos casos analisados por ele têm algum diploma do Ensino Superior.

7 Mais uma vez tomando como parâmetro o trabalho de Rodrigues (2002), que se limita a uma única legislatura, ele encontrou os seguintes números: 31\% em Direito, 13,1\% em Medicina e 11,7\% em Engenharia. Os índices encontrados para o Maranhão estão com porcentagens nos três principais cursos acima daqueles que Rodrigues determinou, especialmente no caso da Engenharia. Chama-nos também a atenção a alta porcentagem de parlamentares formados em Direito no Rio Grande do Sul comparativamente àqueles formados em Medicina e Engenharia.
} 
Grande do Sul) e Engenharia (21,1\% contra 5,7\%) e há maior concentração nos três principais cursos (Direito, Medicina e Engenharia).

QUADRO 3 - PRIMEIRO DIPLOMA DE NÍVEL SUPERIOR OBTIDO

\begin{tabular}{|l|c|c|c|c|}
\hline PRIMEIRO TíTULO & \multicolumn{3}{|c|}{ RS } & \multicolumn{2}{c|}{ MA } \\
\cline { 2 - 6 } OBTIDO & $\mathbf{N .}$ & $\%$ & N. & $\%$ \\
\hline Direito & $110^{8}$ & 63,2 & 35 & 41,2 \\
Medicina & 10 & 5,7 & 15 & 17,7 \\
Engenharia & 10 & 5,7 & 18 & 21,1 \\
Administração & 5 & 2,9 & 4 & 4,7 \\
Economia & 15 & 8,6 & 5 & 5,8 \\
Medicina & 4 & 2,3 & 1 & 1,1 \\
Veterinária & & & & \\
Agronomia & 2 & 1,2 & 1 & 1,1 \\
Comunicação & 4 & 2,3 & - & - \\
Social & & & & \\
Ciências Humanas & 8 & 4,6 & 4 & 4,7 \\
em geral & & & & \\
Farmácia & - & - & 2 & 2,3 \\
Odontologia & 5 & 2,9 & - & - \\
Matemática & 1 & 0,6 & - & - \\
Total & 174 & 100 & 85 & 100 \\
\hline
\end{tabular}

FONTES: o autor, a partir de Abreu et alii (2001) e entrevistas.

NOTA: Quando o deputado possui mais de um título superior foi considerado o primeiro.

Os dados sobre o tipo de instituição de Ensino Superior em que foi obtido o título reforçam novamente a constatação de uma diversificação social maior da "elite política gaúcha" e uma concentração maior em termos de segmentos sociais de origem da "elite política maranhense". Entre os deputados com título superior, os números referentes àqueles que obtiveram diplomas nas instituições públicas (federal e estadual) situadas na capital assemelham-se (pouco mais de $45 \%$ dos casos). O que os diferencia significativamente é o peso no Rio Grande do Sul das instituições públicas situadas no interior e das instituições particulares na capital ou no interior, em contraposição à importância no Maranhão das instituições públicas e particulares de outros estados.

\footnotetext{
8 Nota-se que o número de deputados com formação em Direito é maior que o número de deputados que exerceram a advocacia. Isso se deve a que uma parte dos parlamentares formados em Direito obteve o título quando já ocupava cargos eletivos.
}

QUADRO 4 - TIPO DE INSTITUIÇÃO DE ENSINO SUPERIOR

\begin{tabular}{|c|c|c|c|c|}
\hline \multirow{2}{*}{$\begin{array}{l}\text { TIPO DE } \\
\text { INSTITUIÇÃO } \\
\text { SUPERIOR }\end{array}$} & \multicolumn{2}{|c|}{ RS } & \multicolumn{2}{|c|}{ MA } \\
\hline & $N$ & $\%$ & $N$ & $\%$ \\
\hline Públicas da capital & 80 & 46 & 40 & 47 \\
\hline $\begin{array}{l}\text { Públicas de outros } \\
\text { estados }\end{array}$ & 8 & 4,5 & 41 & 48,2 \\
\hline Públicas do interior & 20 & 11,5 & 0 & 0 \\
\hline $\begin{array}{l}\text { Particulares da } \\
\text { capital }\end{array}$ & 31 & 17,6 & 1 & 1,1 \\
\hline $\begin{array}{l}\text { Particulares do } \\
\text { interior }\end{array}$ & 35 & 20,1 & 0 & 0 \\
\hline $\begin{array}{l}\text { Particulares de } \\
\text { outros estados }\end{array}$ & 0 & 0 & 3 & 3,5 \\
\hline Total & 174 & 100 & 85 & 100 \\
\hline
\end{tabular}

FONTES: o autor, a partir de Abreu et alii (2001) e entrevistas.

Sendo assim, o tipo de instituição na qual foi concluído o curso universitário impõe-se como um indicador potente para a verificação da acentuada diversificação social da "elite política gaúcha” ao contrário do caráter mais fechado da "elite política maranhense". Os trunfos permitidos pelo acesso ao Ensino Superior (título, relações e socialização no movimento estudantil, entre outros) são extremamente relevantes para o desdobramento das carreiras políticas. Portanto, quando as instituições de ensino são mais variadas e mais próximas das "comunidades" de origem, existem condições favoráveis para que segmentos cada vez mais distintos ingressem no âmbito universitário e nele iniciem itinerários políticos ascendentes. Diferentemente, quando essas instituições são mais raras e as opções são mais restritas, somado à distância em termos geográficos, agravam-se os dispêndios de tempo, recursos e energia necessários para freqüentá-las; os obstáculos à entrada no sistema de Ensino Superior avolumam-se e, conseqüentemente, avolumam-se os entraves à reconversão dos possíveis recursos extraídos para a política. Esse fator é, então, simultaneamente causa e conseqüência de dada composição do perfil das "elites políticas estaduais" e incidem sobre padrões de carreiras (mais eletivas ou de cargos públicos, ascendente a partir de cargos locais ou de "ingresso por cima"), de que trataremos na próxima seção.

Ao longo do período analisado (1945-2006) os deputados federais do Rio Grande do Sul passaram cada vez com maior freqüência por insti- 
tuições públicas e privadas localizadas no interior. Em contrapartida, os deputados federais do Maranhão permaneceram submetidos a praticamente apenas duas escolhas: instituições públicas na capital e instituições públicas (principalmente) e particulares fora do estado (geralmente em "centros" maiores).

QUADRO 5 - TIPO DE INSTITUIÇÃO DE ENSINO SUPERIOR POR ANO DAS ELEIÇÕES (RS)

\begin{tabular}{|c|c|c|c|c|c|c|c|c|c|c|c|c|c|c|c|c|}
\hline \multirow[t]{2}{*}{ INSTITUIÇÕES } & \multicolumn{16}{|c|}{ ELEIÇÕES } \\
\hline & 总 & 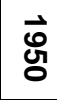 & 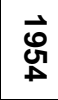 & $\begin{array}{l}\mathscr{o} \\
\text { : }\end{array}$ & 畩 & ஓ্ & $\overrightarrow{0}$ & $\stackrel{\bullet}{\vec{D}}$ & $\stackrel{\bullet}{0}$ & 总 & 足 & $\vec{\sharp}$ & $\stackrel{\bullet}{\sharp}$ & $\stackrel{\bullet}{\bullet}$ & : & : \\
\hline $\begin{array}{l}\text { Públicas da } \\
\text { Capital }\end{array}$ & 12 & 12 & 10 & 13 & 17 & 15 & 8 & 9 & 7 & 9 & 6 & 10 & 7 & 8 & 7 & 7 \\
\hline $\begin{array}{l}\text { Públicas Outros } \\
\text { Estados }\end{array}$ & 3 & 1 & 2 & 1 & - & - & - & - & - & - & - & 1 & 1 & 1 & 1 & - \\
\hline $\begin{array}{l}\text { Públicas } \\
\text { Interior }\end{array}$ & - & 2 & 2 & 2 & - & 1 & 1 & 4 & 4 & 6 & 4 & 4 & 6 & 5 & 2 & 2 \\
\hline $\begin{array}{l}\text { Particulares } \\
\text { Capital }\end{array}$ & - & 1 & 1 & 3 & 3 & 4 & 5 & 8 & 7 & 7 & 9 & 6 & 2 & 2 & 4 & 7 \\
\hline $\begin{array}{l}\text { Particulares } \\
\text { Interior }\end{array}$ & - & - & - & - & - & - & 1 & 3 & 6 & 5 & 5 & 6 & 8 & 13 & 11 & 9 \\
\hline $\begin{array}{l}\text { Particulares } \\
\text { Outros Estados }\end{array}$ & - & - & - & - & - & - & - & - & - & - & - & - & - & - & & - \\
\hline Total & 15 & 16 & 15 & 19 & 20 & 20 & 15 & 24 & 24 & 27 & 24 & 27 & 24 & 29 & 25 & 25 \\
\hline
\end{tabular}

FONTES: o autor, a partir de Abreu et alii (2001) e entrevistas.

QUADRO 6 - TIPO DE INSTITUIÇÃO DE ENSINO SUPERIOR POR ANO DAS ELEIÇÕES (MA)

\begin{tabular}{|c|c|c|c|c|c|c|c|c|c|c|c|c|c|c|c|c|}
\hline \multirow[t]{2}{*}{ INSTITUIÇÕES } & \multicolumn{16}{|c|}{ ELEIÇÕES } \\
\hline & 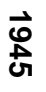 & $\begin{array}{l}\text { ம } \\
\text { ్ㅣㅇ }\end{array}$ & ๒્ఝ & $\begin{array}{l}\text { ம } \\
\text { U్ }\end{array}$ & 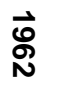 & ஜே & $\stackrel{\bullet}{\mathscr{d}}$ & $\underset{\bullet}{\stackrel{D}{D}}$ & $\underset{\infty}{\stackrel{\bullet}{ు}}$ & $\begin{array}{l}\stackrel{\bullet}{\circ} \\
\stackrel{\infty}{N}\end{array}$ & $\begin{array}{l}\stackrel{\bullet}{\circ} \\
\stackrel{0}{\circ}\end{array}$ & ஜ & 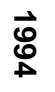 & $\stackrel{\bullet}{\bullet}$ & 옹 & 옹 \\
\hline $\begin{array}{l}\text { Públicas da } \\
\text { Capital }\end{array}$ & 1 & 2 & 1 & 3 & 5 & 5 & 2 & 4 & 5 & 7 & 8 & 8 & 8 & 8 & 11 & 12 \\
\hline $\begin{array}{l}\text { Públicas Outros } \\
\text { Estados }\end{array}$ & 6 & 7 & 7 & 5 & 5 & 9 & 4 & 2 & 3 & 3 & 6 & 10 & 10 & 7 & 5 & 3 \\
\hline $\begin{array}{l}\text { Públicas } \\
\text { Interior }\end{array}$ & - & - & - & - & - & - & - & - & - & - & - & - & - & - & - & - \\
\hline $\begin{array}{l}\text { Particulares } \\
\text { Capital }\end{array}$ & - & - & - & - & - & - & - & - & - & - & - & - & - & - & - & 1 \\
\hline $\begin{array}{l}\text { Particulares } \\
\text { Interior }\end{array}$ & - & - & - & - & - & - & - & - & - & - & - & - & - & - & - & - \\
\hline $\begin{array}{l}\text { Particulares } \\
\text { Outros Estados }\end{array}$ & - & - & - & - & 1 & - & - & - & - & 1 & 1 & 2 & 2 & 1 & 1 & - \\
\hline Total & 7 & 9 & 8 & 8 & 11 & 14 & 6 & 6 & 8 & 11 & 15 & 20 & 20 & 16 & 17 & 16 \\
\hline
\end{tabular}

FONTES: o autor, a partir de Abreu et alii (2001) e entrevistas.

\section{II.1. Profissionalização e carreiras políticas}

Os estudos sobre a profissionalização política em linhas gerais apontam para dois processos interdependentes: a concentração dos mandatos por um número reduzido de agentes e a perma- nência desses agentes em cargos eletivos e políticos por um período longo de tempo (cf. GARRAUD, 1989; OFFERLÉ, 1999; PHELIPPEAU, 2002). Um conjunto de indicadores é utilizado para descrever tais lógicas de funcionamento da política, entre os quais podemos 
citar: a idade e o cargo de ingresso na carreia política; o tempo de ocupação de cargos públicos e o número de candidaturas.

As informações sobre idade e cargos de ingresso são elucidativas da escolha da carreira política em detrimento de outras opções de profissões em pauta para os agentes, pois permitem perceber em que medida essa atividade implica ou não recrutamento precoce, assim como se ocorrem por posições periféricas ou centrais. Logo, evidenciam se a carreira política está pautada por um aprendizado lento, gradual e progressivo (iniciado muito cedo e incluindo a passagem por diferentes cargos da hierarquia política e pouca dedicação a outras atividades profissionais) como exigência para a afirmação ou para a ascensão na arena. Os números concernentes ao tempo de ocupação de cargos atestam o desligamento da profissão de origem e a dedicação mais ou menos intensa à carreira eletiva ou política. Por seu turno, o número de candidaturas indica a monopolização não só de funções eletivas, mas de investiduras partidárias (monopólio de cargos eletivos e partidários).

Com base nos dados coletados é possível observar que mais da metade dos parlamentares dos dois estados iniciaram-se na carreira eletiva (ou seja, ocuparam o primeiro cargo conquistado em pleitos eleitorais) com menos de 35 anos. Esse ingresso precoce torna-se ainda mais visível quando se considera a idade nos primórdios da ocupação dos cargos (incluindo eletivos e nomeados): mais de $70 \%$ dos agentes estrearam com idade inferior a 35 anos, mais da metade antes dos 30 anos e entre $23 \%$ no Rio Grande do Sul e 25\% no Maranhão antes dos 25 anos.

Ainda no tocante à idade, a comparação entre as configurações regionais aponta para uma variação relativa à forma de entrada na política dos agentes que iniciaram suas carreiras relativamente jovens. O Rio Grande do Sul apresenta maiores índices de ingresso precoce na carreira eletiva, ou seja, nesse estado mais de $40 \%$ dos agentes começaram sua atuação antes dos 30 anos, contra $28 \%$ no Maranhão. Por sua vez, quando considerada a idade de ocupação do primeiro cargo público, em ambos os estados encontram-se índices que se aproximam de $60 \%$ de entrada antes dos 30 anos. Essa constatação está ligada à tendência do início na carreira por cargos eletivos no Rio Grande do Sul e por cargos públicos no Maranhão.
QUADRO 7 - IDADE DE INGRESSO NA CARREIRA ELETIVA

\begin{tabular}{|l|c|c|c|c|}
\hline \multirow{2}{*}{ IDADE } & \multicolumn{2}{|c|}{ RS } & \multicolumn{2}{c|}{ MA } \\
\cline { 2 - 5 } & $\boldsymbol{N}$. & \% & $\boldsymbol{N .}$ & $\%$ \\
\hline $18-25$ & 30 & 15 & 11 & 11 \\
$26-30$ & 55 & 27,5 & 17 & 17 \\
$31-35$ & 33 & 16,5 & 20 & 20 \\
$36-40$ & 37 & 18,5 & 29 & 29 \\
+ de 40 & 45 & 22,5 & 23 & 23 \\
Total & 200 & 100 & 100 & 100 \\
\hline
\end{tabular}

FONTES: o autor, a partir de Abreu et alii (2001) e entrevistas.

QUADRO 8 - IDADE DE INGRESSO NA CARREIRA POLÍTICA

\begin{tabular}{|l|c|c|c|c|}
\hline \multirow{2}{*}{ IDADE } & \multicolumn{2}{|c|}{ RS } & \multicolumn{2}{c|}{ MA } \\
\cline { 2 - 5 } & $\boldsymbol{N}$. & $\%$ & $\boldsymbol{N}$. & $\%$ \\
\hline $18-25$ & 46 & 23 & 25 & 25 \\
$26-30$ & 67 & 33,5 & 34 & 34 \\
$31-35$ & 29 & 14,5 & 16 & 16 \\
$36-40$ & 31 & 15,5 & 15 & 15 \\
+ de 40 & 27 & 13,5 & 10 & 10 \\
Total & 200 & 100 & 100 & 100 \\
\hline
\end{tabular}

FONTES: o autor, a partir de Abreu et alii (2001) e entrevistas.

Cotejando as informações por estado sobre o primeiro cargo eletivo ocupado, as dessemelhanças entre os padrões regionais vêm à tona, uma vez que $39,5 \%$ dos deputados federais do Rio Grande do Sul ingressaram na carreira política via posições eletivas locais (vereança, vice-Prefeitura e Prefeitura) contra 13\% do Maranhão. Ademais, $50 \%$ dos deputados federais do Maranhão iniciaram-se em cargos políticos administrativos, logo não-eletivos (somando cargos de primeiro e segundo escalões nos níveis municipal, estadual e federal) contra $25 \%$ no Rio Grande do Sul. Examinando os deputados federais que começaram a carreira política diretamente pelo parlamento estadual ou nacional não se percebem diferenças significativas entre os estados.

Tais padrões são corroborados com a verificação das informações sobre o cargo de ingresso na carreira eletiva (primeiro cargo eletivo ocupado). Os dados mostram que, no Rio Grande do Sul, 47\% dos deputados federais começaram a carreira eletiva por posições locais, como vereadores (39\%), vice-prefeitos e prefeitos (8\% somados), contra apenas $18 \%$ no Maranhão que iniciaram por posições do mesmo tipo, isto é, como 
vereadores (12\%) e como prefeitos e vice-prefeitos (6\%). Contrariamente, no Maranhão 80\% dos agentes investigados debutaram na ocupação de cargos eletivos como deputados federais (44\%) ou estaduais (36\%), contra 53\% no Rio Grande do Sul que ingressaram pelos mesmos cargos ( $27 \%$ e $26 \%$, respectivamente). Dois dados merecem destaque: 1 ) dos deputados federais analisados no Rio Grande do Sul 39\% e no Maranhão $12 \%$, iniciaram suas carreiras eletivas como vereadores; 2) dos deputados gaúchos, $27 \%$ chegam diretamente à Câmara dos Deputados sem passar por vereança, Prefeitura ou deputação estadual; para os maranhenses, esse índice é de $44 \%$.

QUADRO 9-CARGO DE INGRESSO NA CARREIRA POLÍTICA

\begin{tabular}{|l|c|c|c|c|}
\hline \multirow{2}{*}{ CARGO } & \multicolumn{2}{|c|}{ RS } & \multicolumn{2}{c|}{ MA } \\
\cline { 2 - 6 } & $\mathbf{N .}$ & \% & N. & $\%$ \\
\hline Vereador & 67 & 33,5 & 9 & 9 \\
Deputado estadual & 34 & 17 & 21 & 21 \\
$\begin{array}{l}\text { Deputado federal } \\
\text { Prefeito/Vice- }\end{array}$ & 37 & 18,5 & 16 & 16 \\
prefeito & 12 & 6 & 4 & 4 \\
$\begin{array}{l}\text { Cargos } \\
\text { administrativos }\end{array}$ & 50 & 25 & 50 & 50 \\
(nomeação) & & & & \\
Total & 200 & 100 & 100 & 100 \\
\hline
\end{tabular}

FONTES: o autor, a partir de Abreu et alii (2001) e entrevistas.

O primeiro cargo conquistado na carreira eletiva, assim como o local de escolarização superior verificado anteriormente, é um indicador consistente que permite cotejar as duas populações e demonstrar os processos de diversificação social e ampliação relativa do acesso à "elite polí-
QUADRO 10 - CARGO DE INGRESSO NA CARREIRAELETIVA

\begin{tabular}{|l|l|l|l|l|}
\hline \multirow{2}{*}{ CARGO } & \multicolumn{2}{|c|}{ RS } & \multicolumn{2}{c|}{ MA } \\
\cline { 2 - 5 } & \multicolumn{1}{|c|}{ N. } & \multicolumn{1}{c|}{$\%$} & N. & \% \\
\hline Vereador & 78 & 39 & 12 & 12 \\
Deputado Estadual & 52 & 26 & 36 & 36 \\
Deputado Federal & 54 & 27 & 44 & 44 \\
Prefeito e vice- & 16 & 8 & 6 & 6 \\
Prefeito & & & & \\
Vice-Governador & - & - & 2 & 2 \\
Total & 200 & 100 & 100 & 100 \\
\hline
\end{tabular}

FONTES: o autor, a partir de Abreu et alii (2001) e entrevistas.

tica” no Rio Grande do Sul e de controle das oportunidades políticas por parte de uma "elite política” mais "fechada” no Maranhão. Quando se observam os percursos políticos seguidos pelos agentes que iniciaram suas carreiras por posições periféricas (principalmente Vereador) e alcançaram posições de destaque da política estadual (como é o caso do cargo de Deputado Federal), evidenciase um espaço político mais competitivo e aberto. Quando prevalece o "ingresso por cima” na carreira política eletiva, quer dizer, diretamente pela ocupação de cargos mais altos na hierarquia política, o controle e a seleção prévia por parte dos agentes já estabelecidos ou das máquinas políticas mostram-se decisivos. No decorrer do período estudado (1945-2006) constata-se o aumento, principalmente a partir da década de 1970 , de deputados federais gaúchos que começaram sua carreira eletiva como vereadores. Já os deputados federais maranhenses continuaram debutando em cargos eletivos principalmente como deputados federais e estaduais.

QUADRO 11 - CARGOS INGRESSO NA CARREIRA ELETIVAPOR ANO DAS ELEIÇÕES (RS)

\begin{tabular}{|c|c|c|c|c|c|c|c|c|c|c|c|c|c|c|c|c|}
\hline \multirow[t]{2}{*}{ CARGOS } & \multicolumn{16}{|c|}{ ELEIÇÕES } \\
\hline & 仓े & 包 & 它 & 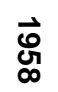 & 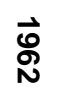 & மே & $\stackrel{\bullet}{0}$ & $\stackrel{\vec{D}}{\vec{D}}$ & $\underset{\infty}{\mathfrak{d}}$ & $\begin{array}{l}\stackrel{\leftrightarrow}{0} \\
\stackrel{0}{N}\end{array}$ & ڤ & ஜ & $\stackrel{\bullet}{\bullet}$ & $\ddot{\emptyset}$ & ్ㅗㅇ & 옹 \\
\hline Vereador & - & 3 & 1 & 1 & 3 & 3 & 10 & 16 & 16 & 15 & 12 & 10 & 10 & 20 & 14 & 13 \\
\hline $\begin{array}{l}\text { Prefeito e } \\
\text { vice-Prefeito }\end{array}$ & 2 & - & - & - & 2 & 3 & 2 & 4 & 4 & 2 & - & 2 & 3 & 3 & 1 & 1 \\
\hline $\begin{array}{l}\text { Deputado } \\
\text { Estadual }\end{array}$ & 5 & 7 & 12 & 11 & 11 & 11 & 3 & 3 & 3 & 6 & 4 & 7 & 3 & 1 & 4 & 5 \\
\hline $\begin{array}{l}\text { Deputado } \\
\text { Federal } \\
\text { Vice- } \\
\text { Governador }\end{array}$ & 8 & 6 & 4 & 6 & 9 & 7 & 5 & 5 & 5 & 5 & 11 & 10 & 10 & 8 & 7 & 5 \\
\hline Total & 15 & 16 & 17 & 18 & 25 & 24 & 20 & 28 & 28 & 28 & 27 & 29 & 26 & 32 & 26 & 24 \\
\hline
\end{tabular}

FONTES: o autor, a partir de Abreu et alii (2001) e entrevistas. 
QUADRO 12 - CARGOS INGRESSO NA CARREIRA ELETIVA POR ANO DAS ELEIÇÕES (MA)

\begin{tabular}{|c|c|c|c|c|c|c|c|c|c|c|c|c|c|c|c|c|}
\hline \multirow[t]{2}{*}{ CARGOS } & \multicolumn{16}{|c|}{ ELEIÇÕES } \\
\hline & 它 & 兽 & $\stackrel{\bullet}{\mathscr{f}}$ & ث્ષ & 总 & ๖े & $\stackrel{\bullet}{0}$ & $\stackrel{\leftrightarrow}{\Phi}$ & $\underset{\infty}{\bullet}$ & 芯 & $\stackrel{\bullet}{\circ}$ & 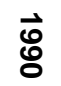 & $\stackrel{\bullet}{\not}$ & $\stackrel{\bullet}{\bullet}$ & 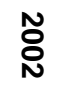 & ัิ \\
\hline Vereador & - & 2 & - & 1 & 1 & - & - & 1 & 2 & - & 3 & 2 & 2 & 1 & $\frac{1}{1}$ & 3 \\
\hline $\begin{array}{l}\text { Prefeito e } \\
\text { vice- } \\
\text { Prefeito }\end{array}$ & - & - & - & - & 1 & 1 & - & - & 1 & 1 & 1 & 1 & 2 & 2 & 2 & - \\
\hline $\begin{array}{l}\text { Deputado } \\
\text { Estadual }\end{array}$ & 3 & 1 & 3 & 2 & 5 & 7 & 2 & 5 & 6 & 7 & 10 & 9 & 12 & 9 & 8 & 7 \\
\hline $\begin{array}{l}\text { Deputado } \\
\text { Federal }\end{array}$ & 7 & 6 & 6 & 6 & 6 & 8 & 4 & 3 & 4 & 8 & 5 & 8 & 5 & 9 & 11 & 8 \\
\hline $\begin{array}{l}\text { Vice- } \\
\text { Governador }\end{array}$ & - & - & - & 1 & 1 & 2 & - & - & - & - & - & 1 & - & - & - & - \\
\hline Total & 10 & 9 & 9 & 10 & 14 & 18 & 6 & 9 & 13 & 16 & 19 & 21 & 21 & 21 & 22 & 18 \\
\hline
\end{tabular}

Fontes: o autor, a partir de Abreu et alii (2001) e entrevistas.

Tal discrepância nos padrões de carreiras traduz-se igualmente nas diferenças quanto à experiência eletiva prévia à chegada ao cargo de Deputado Federal. Somando os anos de cargos eletivos que os deputados federais exerceram ou alcançaram antes de elegerem-se deputados pela primeira vez, revela-se mais uma vez a variação regional. Analisando-se o quadro abaixo, percebe-se que 28,5\% dos casos analisados do Rio Grande do Sul e apenas $10 \%$ dos casos analisados do Maranhão desempenharam ou conquistaram nas urnas mais de oito anos de mandatos eletivos antes de chegarem ao Congresso Nacional. E 73\% (quase 3/4) dos parlamentares maranhenses chegaram à Câmara dos Deputados com menos de quatro anos de mandatos eletivos conquistados, contra $47,5 \%$ - menos da metade - dos parlamentares gaúchos.

QUADRO 13 - EXPERIÊNCIAELETIVA PRÉVIAAO MANDATO DE DEPUTADO FEDERAL

\begin{tabular}{l|cc|c|c|}
\hline \multirow{2}{*}{ ANOS DE CARGOS } & \multicolumn{2}{|c|}{ RS } & \multicolumn{2}{c|}{ MA } \\
\cline { 2 - 5 } ELETIVOS PRÉVIOS & $\mathbf{N .}$ & $\%$ & $\mathbf{N .}$ & $\%$ \\
\hline 0 & 56 & 28 & 44 & 44 \\
$1-4$ & 39 & 19,5 & 29 & 29 \\
$5-8$ & 48 & 24 & 17 & 17 \\
+ de 8 & 57 & 28,5 & 10 & 10 \\
Total & 200 & 100 & 100 & 100 \\
\hline FONTES: o autor, a partir de Abreu et alii (2001) e entre- \\
vistas.
\end{tabular}

Os dados apresentados até aqui conformam padrões de carreiras e de profissionalização política e são reforçados pela exposição de informações referentes ao tempo de mandato eletivo, ao tempo de ocupação de cargos políticos e ao nú- mero de candidaturas. Essas últimas informações foram coletadas somente entre aqueles deputados que estão afastados das disputas políticas. Foram, portanto, excluídos os ocupantes de mandatos entre 2000 e 2006 e aqueles que concorreram a cargos eletivos no mesmo período, pois sua inclusão acarretaria prejuízo no poder de explicação dos indicadores. Contabilizar os deputados em plena carreira (alguns mesmo no seu início) implicaria a tendência à redução dos índices de tempo de ocupação de cargos e de número de candidaturas.

De modo geral, prevalecem as carreiras políticas longas em termos de tempo de ocupação de cargos: mais de $70 \%$ dos deputados ultrapassaram 16 anos e mais da metade ultrapassaram 20 anos de cargos políticos. De modo específico, entre os deputados gaúchos, acima de $65 \%$ deles ultrapassam 16 anos de mandatos eletivos, ao passo que entre os maranhenses esse índice é de $50 \%$. Sendo assim, observa-se o maior peso dos cargos eletivos no tempo total de carreira para os deputados do Rio Grande do Sul e o maior peso dos cargos públicos no tempo total de carreira para aqueles do Maranhão.

QUADRO 14 - TEMPO DE CARREIRA POLITICA
\begin{tabular}{|l|c|c|c|c|}
\hline \multirow{2}{*}{ Anos } & \multicolumn{2}{|c|}{ RS } & \multicolumn{2}{c|}{ MA } \\
\cline { 2 - 5 } & $\boldsymbol{N}$. & $\%$ & $\boldsymbol{N}$. & $\%$ \\
\hline 10 ou - & 17 & 13,6 & 4 & 10 \\
$11-15$ & 15 & 12 & 4 & 10 \\
$16-20$ & 24 & 19,2 & 10 & 25 \\
+ de 20 & 69 & 55,2 & 22 & 55 \\
Total & 125 & 100 & 40 & 100 \\
\hline
\end{tabular}

FONTES: o autor, a partir de Abreu et alii (2001) e entrevistas. 


\section{QUADRO 15 - TEMPO DE CARREIRA ELETIVA}

\begin{tabular}{|l|cc|c|c|}
\hline \multirow{2}{*}{ ANOS } & \multicolumn{2}{|c|}{ RS } & \multicolumn{2}{c|}{ MA } \\
\cline { 2 - 5 } & $\boldsymbol{N}$. & $\%$ & $\boldsymbol{N}$. & $\%$ \\
\hline 10 ou - & 26 & 20,8 & 11 & 27,5 \\
$11-15$ & 17 & 13,6 & 9 & 22,5 \\
$16-20$ & 41 & 32,8 & 8 & 20 \\
+ de 20 & 41 & 32,8 & 12 & 30 \\
Total & 125 & 100 & 40 & 100 \\
\hline
\end{tabular}

FONTES: o autor, a partir de Abreu et alii (2001) e entrevistas.

Deve-se salientar também que mais de $60 \%$ dos deputados nos dois estados concorreram cinco vezes ou mais a cargos eletivos e apenas $8,8 \%$ dos deputados gaúchos e $12 \%$ dos deputados maranhenses concorreram uma ou duas vezes.

QUADRO 16 - NÚMERO DE CANDIDATURAS

\begin{tabular}{|l|c|c|c|c|}
\hline \multirow{2}{*}{ CANDIDATURAS } & \multicolumn{2}{|c|}{ RS } & \multicolumn{2}{c|}{ MA } \\
\cline { 2 - 5 } & N. & $\%$ & N. & $\%$ \\
\hline $1-2$ & 11 & 8,8 & 5 & 12,5 \\
$3-4$ & 30 & 24 & 11 & 27,5 \\
$5-6$ & 40 & 32 & 15 & 37,5 \\
7 ou + & 44 & 35,2 & 9 & 22,5 \\
Total & 125 & 100 & 40 & 100 \\
\hline
\end{tabular}

FONTES: o autor, a partir de Abreu et alii (2001) e entrevistas.

Ao monopólio de cargos eletivos, de cargos políticos e de candidaturas, soma-se o controle dos mesmos por um conjunto de "famílias de políticos” em ambos os contextos examinados. A pesquisa permitiu identificar que $50 \%$ dos deputados federais do Rio Grande do Sul e 70\% dos deputados federais do Maranhão possuem parentes que ocuparam ou ocupam cargos eletivos. No conjunto da população analisada em cada estado, 25\% no Rio Grande do Sul e 30\% no Maranhão têm ascendentes que exerceram ou exercem cargos eletivos; $16 \%$ no Rio Grande do Sul e 22\% no Maranhão possuem descendentes que ocuparam ou ocupam cargos eletivos; 31\% no Rio Grande do Sul e 40\% no Maranhão têm membros da mesma geração na "família" que desempenharam ou desempenham cargos eletivos. Ademais, o número de parentes com cargos eletivos em um mesmo grupo familiar é outro dado importante. No Rio Grande do Sul 10\% dos deputados têm, no mínimo, cinco parentes que ocuparam ou ocupam cargos eletivos, enquanto no Maranhão a porcentagem chega a $15 \%$. Mais de $30 \%$ dos deputados gaúchos e $42 \%$ dos deputados maranhenses possuem entre dois e quatro parentes que ocuparam ou ocupam cargos eletivos, sem desconsiderar que 30\% dos deputados gaúchos e $47 \%$ dos deputados maranhenses pertencem a "famílias de políticos" de duas, três ou quatro gerações de ocupantes de cargos eletivos. Os dados demonstram, então, um peso maior do vínculo de parentesco entre políticos ocupantes de mandatos eletivos no Maranhão, mas indicam uma significativa presença também de laços familiares entre a "elite política” gaúcha9 .

\section{DIVERSIFICAÇÃO SOCIAL E PADRÕES DE ESPECIALIZAÇÃO (1945-2006)}

Após examinar os padrões de especialização política nos dois estados e confrontar as bases sociais e políticas de profissionalização, nesta seção apresentaremos um panorama longitudinal e diacrônico que permite caracterizar as dinâmicas de concorrência e de alianças entre agentes oriundos de segmentos sociais distintos e engajados em carreiras cada vez mais profissionalizadas. Assim, pretende-se expor os elementos que interferem na própria constituição dos espaços políticos. A análise que segue centra-se, então, nos processos de reconversão, reprodução, ascensão e afirmação de agentes e "famílias de políticos" ao longo do século XX, sobretudo a partir de 1945. Seguindo as diretrizes de Norbert Elias (2001) para o estudo da sociogênese da profissão naval na Inglaterra ${ }^{10}$ e a aplicação das mesmas orientações feita por Eric Phelippeau (1999; 2001; 2002) para

9 Seria necessária uma análise mais minuciosa para verificar o peso entre os agentes com parentesco com outros políticos da "hereditariedade política" (a contribuição familiar para predispor os agentes a investirem na carreira) e da "hereditariedade eletiva" (o parentesco como um recurso eleitoral) (cf. GARRAUD, 1989). Além disso, os repertórios biográficos ainda são pouco confiáveis na tarefa de detectar tais informações, apenas apresentando os casos de maior notoriedade.

10 Como sugere Norbert Elias (2001), cumpre perceber como o processo histórico de constituição de uma profissão implica a complementaridade entre diferenciação e integração, entre especialização e fusão. Os conflitos e tensões entre agentes com origens em camadas sociais diferenciadas (características sociais, estilos de vida, auto-percepções da sua posição social diversa), assim como a formação, o treinamento e as carreiras distintas que definem os ingressos em um domínio em vias de profissionalização 
a análise da invenção do "homem político” na França, o acento aqui recai sobre as tensões microscópicas, as entradas e as defecções, as osmoses e as interpenetrações entre agentes provenientes de extrações sociais diferenciadas.

O período inaugurado com a queda do Estado Novo marcou um dos "ciclos de redemocratização” na política brasileira. A dinâmica da disputa partidária e os padrões de comportamento eleitoral no período são aspectos estudados em detalhe pela Ciência Política no Brasil ${ }^{11}$. No referido período, apesar da instabilidade do "sistema político" brasileiro, verifica-se a diversificação social e ideológica da "elite política", com o ingresso de agentes oriundos de segmentos sociais distintos e a redefinição dos repertórios de mobilização acionados por ocupantes de cargos eletivos. No entanto, pouca atenção tem sido dada para as transformações na composição da "elite política”, suas origens sociais, a diversificação das bases sociais de recrutamento e as conseqüências na reconfiguração do espaço político no país (entre as exceções, encontra-se o trabalho de Miceli (1981)).

Estudos com ênfase institucional que se debruçaram sobre o novo "ciclo de redemocratização" e a instauração do multipartidarismo, a partir do final dos anos 1970, deslocaram o debate para as relações entre os poderes Executivo e Legislativo; a disciplina ou a coesão das bancadas no Congresso Nacional e nas assembléias legislativas; as coligações e as migrações partidárias; os resultados eleitorais etc. Avaliações mais ou menos críticas e conflitantes entre si sobre o sistema partidário vigente de lá para cá passaram a dominar a agenda ${ }^{12}$; ao mesmo tempo, desenvolveram-se alguns trabalhos mais isolados sobre perfis, recursos, recrutamento e composição social das “elites políticas” (MARENCO, 2000;

produzem divisão de tarefas ou de atribuições, rivalidades e lutas. No entanto, fabricam ao mesmo tempo funções sociais que mesclam as habilidades e as competências dos agentes e pautam padrões e códigos inovadores para as relações humanas entre profissionais e destes com os "profanos".

11 Para uma revisão bibliográfica sobre o período, ver Cánepa (1999, p. 52-59).

12 Alguns importantes balanços da literatura sobre o período podem ser encontrados em Marenco (2000) e em Rodrigues (2002).
CORADINI, 2001; 2007; RODRIGUES, 2002; 2006).

Entre os aspectos que parecem ainda não privilegiados pelos analistas das competições políticas ocorridas ao longo da segunda metade do século XX e início do século XXI, estão os mecanismos responsáveis pela presença em cargos eletivos de agentes que pertencem a "famílias tradicionais" e pela persistência das mesmas no interior da "elite". Da mesma forma, as entradas na política13, no período 1945-1964, de "descendentes de imigrantes” (alemães, italianos, sírios, libaneses etc.) radicados no Brasil no século XIX e no início do século XX, a reprodução "familiar" na política e o aumento da presença de agentes com essas origens nos momentos subseqüentes não mereceram atenção especial - ainda que alguns autores tenham apresentado pistas importantes nesse sentido (como FAUSTO, 1995; GRÜN, 1995; SAKURAI, 1995; TRUZZI, 1995; CORADINI, 1998B; SEYFERTH, 1999). Também importa frisar a escassez de pesquisas concentradas nos condicionantes e nos efeitos das entradas na política de agentes com origens sociais mais baixas a partir da militância sindical, associativa, partidária etc. (com destaque para Coradini (2001; 2007), Rodrigues (2002; 2006), Marenco e Serna (2007) e Reis (2007)). Menos comuns ainda são os estudos que se lançam a estabelecer comparações entre configurações regionais, mesmo que o fator "federalismo" seja constantemente mencionado na bibliografia de inspiração institucionalista.

Os dados referentes aos perfis dos deputados e às carreiras, assim como à posição social de origem (principal atividade profissional desempenhada pelo ascendente do primeiro ocupante de cargo eletivo na "família") e ao momento de entrada na política do Deputado ou da "família de

13 O termo é usado aqui no sentido proposto por Offerlé (1996, p. 3), “[...] combinando predisposições social e historicamente constituídas para a realização política [...] e a idéia de constituição de uma atividade especializada [...]. Entradas na política no plural, pois trata-se de estudar tanto trajetórias individuais quanto trajetórias coletivas [...]; de perceber de que maneira os novos ingressantes devem adaptar suas propriedades aos condicionantes estruturais da atividade e da profissão política tendencialmente delimitados sem ser fechados ou codificados; de que maneira os ingressantes criam e recriam pela sua concorrência (entre eles e seus predecessores) as condições de possibilidade de sua realização política”. 
políticos” (quando é o caso), permitiram atentar para os processos de especialização em realidades contrastantes e de identificar padrões em concorrência em cada uma delas. Tais informações foram encontradas para 93 deputados federais do Rio Grande do Sul e 42 do Maranhão.

Sendo assim, na seqüência analisaremos três padrões de acesso, afirmação e reprodução no espaço político. O primeiro abarca os "descendentes” das "famílias mais tradicionais", estabelecidas social e politicamente desde o século XIX e início do século XX; o segundo reúne os deputados egressos de "famílias" marcadas por uma "ascensão social” significativa na primeira metade do século XX, com presença preponderante de "descendentes de imigrantes"; o terceiro padrão, minoritária nos dois estados investigados, congrega os casos de ascensão política a partir de origens sociais mais baixas, calcada na atuação militante em diversos espaços.

\section{III.1. “Tradição" e especialização política}

Tanto no Rio Grande do Sul quanto no Maranhão os casos que se aproximam do primeiro padrão compartilham em linhas gerais algumas características. Os "antepassados" dos agentes pertencem às "elites locais” desde o século XIX e o pai do primeiro político na "família" dedicou-se à administração de grandes propriedades rurais, ao comércio urbano estabelecido e às carreiras públicas e militares - sendo que tais ocupações não eram excludentes entre si. O ingresso no âmbito dos cargos eletivos do primeiro membro da "família" geralmente ocorreu ainda no século XIX ou na primeira metade do século XX; quase sempre os deputados debutaram na ocupação de cargos eletivos por postos mais centrais (especialmente pelas deputações estadual e federal). Em geral, obtiveram títulos superiores (sobretudo em Direito, Medicina e Engenharia) em grandes instituições públicas nas capitais de seus estados ou em centros maiores. Nos dois contextos pesaram decisivamente o investimento em títulos escolares e a reconversão dos laços herdados e adquiridos em prestígio no interior de máquinas partidárias estaduais ou nacionais. As variações regionais mais significativas em termos de perfis sociais no interior desse padrão residem no fato de que, diferentemente do Rio Grande do Sul, para os deputados do Maranhão há um peso maior na passagem por cargos políticos não eletivos no início e ao longo das carreiras e em instituições pú- blicas de Ensino Superior em outras capitais do país.

No padrão mais "tradicional” ou estabelecido há mais tempo os deputados federais e membros da "família" com atuação política e eletiva buscam na sua vinculação com o passado político local trunfos para a distinção no espaço de competição ou para a legitimação das suas carreiras políticas. No caso do Rio Grande do Sul, tal elo faz-se com a ativação, nas narrativas oferecidas pelos agentes, da participação de "antepassados" em lutas entre facções políticas e militares que marcaram o cenário estadual no século XIX e no início do século XX, bem como na ênfase dada ao fato de pertencerem aos restritos círculos de elites culturais e econômicas. No caso do Maranhão, a associação estabelecida é com a "imagem" difundida de um apogeu econômico e cultural que se traduzia em um estilo de vida sofisticado e em uma tradição intelectual de diferentes matizes e passíveis de diversos usos.

A referência de síntese que esses agentes acionam nas definições sobre o exercício da atividade política é a de "vocação pública" (ou, nos termos utilizados: para a "coisa pública”, para o "serviço público", para a "doação às funções públicas” etc.). O binômio formado pelas idéias de "vocação" e "público" apóia-se em um conjunto de atributos naturalizados como "formação", "preparo”, “cultura”, "erudição”, “conhecimento”, "poder argumentativo", "tradição de estudo" etc. Como se vê, a vinculação a grupos familiares estabelecidos há mais tempo e o acesso a títulos que durante muito tempo foram raros nas configurações regionais -, fixam um conjunto de "imagens” pessoais e “familiares”. Essas imagens acabam servindo de trunfos para as tentativas de estabelecer distinções em relação aos demais políticos e de proclamar um desempenho político "nobre”, “desinteressado”, “qualificado” etc., pautando modelos de conduta.

Podem ser associados ao padrão Nélson Jobim e Jaime Santana, ex-deputados federais pelo Rio Grande do Sul e pelo Maranhão.

O ex-Deputado Federal Nélson Jobim é descendente de "grandes proprietários" da "metade Sul” do Rio Grande do Sul. Segundo biografia publicada sobre um dos fundadores da Academia Nacional de Medicina, José da Cruz Jobim, a "família Jobim” é originária de uma localidade cha- 
mada Santa Cruz do Jobim, em Portugal. O "fundador" da "família Cruz" no Brasil, que na seqüência passou a ser designada "Jobim”, José Martins da Cruz, era militar. Como tal foi inicialmente enviado para os Açores e posteriormente para o Brasil. Recebeu como retribuição aos seus feitos militares uma "sesmaria de campo" no Rio Grande do Sul e mais tarde foi Juiz de Órfãos, cargo que exerceu até 1816. Assim, o "primeiro membro da família” instalou-se em Rio Pardo, casou-se com uma portuguesa e teve quatro filhos. O mais velho foi Senador do Império e fundador da Academia Nacional de Medicina; outro conquistou o título nobiliárquico de Barão de Cambaí. José Martins da Cruz casou-se pela segunda vez e teve mais quatro filhos, um dos quais foi "agraciado com a Ordem da Rosa no grau de Comendador” (FERNANDES, 1980, p. 248).

De um desses irmãos descende o advogado formado pela Faculdade de Direito de Porto Alegre e filho de funcionário público, Walter Jobim. Ele formou-se em 1913 e estabeleceu-se em Santa Maria nas primeiras décadas do século XX; casou-se com uma descendente de militares (que tiveram destacada atuação na Guerra do Paraguai) e filha de um importante comerciante urbano do mesmo município. Walter Jobim atuou como juiz e promotor. Posteriormente, montou um escritório de advocacia. O exercício dessas profissões auxiliou-o na fixação dos atributos utilizados ao longo da sua carreira política: "capacidade oratória” e "aptidão para a escrita" (JOBIM NETO, 2001). Aliado a isso, sua participação nas lutas políticas ou conflitos militares do período contribuíam para a solidificação da liderança política e a inserção em uma das facções políticas estaduais. Entre 1923 e 1932 participou da "Revolução de 1923” liderada por Assis Brasil; da "Revolução de 1930”, ao lado de Getúlio Vargas, e da Revolução Constitucionalista de 1932. Foi candidato a Intendente de Santa Maria em 1927 pelo Partido Liberal (PL). Depois, em 1935, concorreu à deputação federal, elegendo-se (com 43 anos) ${ }^{14}$.

Walter Jobim passou a ser membro do círculo dirigente da facção política e chegou a importantes secretarias de estado nos anos 1930 e 1940. Entre 1938 e 1945 foi Secretário de Obras e Se-

14 Walter Jobim renunciou a esse cargo em nome de um acordo entre as lideranças dos partidos que compunham a Frente Única Gaúcha, resultante do acordo entre o Partido Liberal e o Partido Republicano Riograndense. cretário de Segurança. Em 1946, Walter Jobim chegou ao ápice da carreira política, elegendo-se Governador do Estado (com 54 anos). Após deixar o governo do estado, foi indicado para ocupar a Embaixada do Brasil em Montevidéu.

Dos filhos de Walter Jobim, dois tiveram funções públicas destacadas: Walter Jobim Filho e Hélvio Jobim. Walter Jobim Filho formou-se em Engenharia e Hélvio Jobim, em Direito; obtiveram seus respectivos títulos superiores em Porto Alegre, na Universidade Federal do Rio Grande do Sul (UFRGS). O engenheiro e professor universitário Walter Jobim Filho ocupou cargos junto aos poderes Executivo estadual e federal, legitimado pelo título escolar, pela formação profissional e pelas redes de relações (políticas e pessoais) acumuladas pelo pai. Atuou no Departamento Nacional de Obras; foi nomeado Diretor Técnico da Eletrosul Centrais Elétricas; escolhido Secretário Estadual de Minas e Energia do Rio Grande do Sul pelo Governador Sinval Guazelli; finalmente, foi indicado pelo então Governador Amaral de Souza para a Presidência da Aços Finos Piratini. Já Hélvio Jobim herdou o reduto local e a inserção profissional por meio da liderança partidária e da advocacia em Santa Maria. Como advogado, Hélvio Jobim assumiu o escritório do pai em 1936; casou-se com a filha de uma "tradicional família" de Santa Maria, líderes militares e políticos (“chimangos”) no município. Foi durante muitos anos Presidente do Partido Social-Democrata (PSD) daquela cidade e concorreu a Deputado Estadual em 1958. Nessa eleição conquistou uma cadeira na Assembléia Legislativa (com 38 anos). Agregou a essa liderança partidária o "nome”, a aliança matrimonial e a atividade como advogado em que se destacava - segundo o depoimento de seu filho - como “excelente tribuno de júri” (idem).

Teve três filhos homens: Walter Jobim Neto, Nélson Jobim e Hélvio Jobim Filho. Nélson Jobim ocupou o primeiro cargo eletivo em 1986 (aos 40 anos). Após encerrar seus estudos de graduação em Direito pela UFRGS, atuou na "Ala Moça da Arena [Aliança Renovadora Nacional]” e no Instituto de Estudos Políticos Tarso Dutra. Foi Diretor do Clube Comercial e membro do Lions Club - assim como boa parte dos membros da "família" - e casou-se com uma filha de grandes fazendeiros da "região". Foi também membro do Instituto dos Advogados do Rio Grande do Sul e do Instituto dos Advogados Brasileiros. Fez o mestrado em Filosofia Analítica e Lógica Mate- 
mática entre 1982 e 1984 e lecionou no curso de Direito da Universidade Federal de Santa Maria (UFSM), na Escola Superior de Magistratura da Associação dos Juízes do Rio Grande do Sul (AJURIS), na Escola Superior do Ministério Público e na Escola Superior de Advocacia da Ordem dos Advogados do Brasil (OAB). Destacouse ainda como presidente da OAB do município e como vice-Presidente e candidato a Presidente Regional da mesma entidade; essa candidatura foi retirada para dedicar-se à campanha à Assembléia Constituinte em 1986, incentivado pelo então Deputado Federal do Partido do Movimento Democrático Brasileiro (PMDB) pelo município e também advogado João Gilberto Lucas Coelho, que concorreu ao Senado Federal. Reelegeu-se em 1990 mas em 1994 não concorreu ao terceiro mandato. Em 1995 foi empossado Ministro da Justiça pelo Presidente da República Fernando Henrique Cardoso; em 1997 foi indicado como Ministro do Supremo Tribunal Federal (STF) e presidiu o Tribunal Superior Eleitoral (TSE) e o próprio STF. Atualmente é Ministro da Defesa de Luís Inácio Lula da Silva.

A caracterização da atuação política familiar centra-se em valores e atributos associados às profissões exercidas e na excelência dos percursos escolares e profissionais. São acionadas categorias como "formação humanística”, "destreza com as palavras", "capacidade profissional”, "vocação política”, "conhecimento generalista”, "visão abrangente”, "poder argumentativo”, "habilidade de debatedor" (idem).

O também ex-Deputado Federal Jaime Manoel Tavares Neiva de Santana descende de "tradicionais famílias" da política maranhense com atuação destacada no "sertão maranhense" (municípios de Pastos Bons e Nova Iorque). Segundo Buzar (2001, p. 275), desde o século XIX “[...] uma luta ferrenha entre duas famílias abalava o sertão maranhense. De uma lado, os Neiva[s], de outro, os Teixeira[s], empenhavam suas forças pelo domínio econômico e política daquela região”.

O seu avô paterno, cearense, radicou-se no estado ainda no século XIX e tornou-se um dos maiores comerciantes e fazendeiros da "região". Contou para tanto com o casamento com a filha de um importante fazendeiro, comerciante e "líder político”. Os avós (paterno e materno) de Jaime Santana foram prefeitos, um dos tios chegou ao Senado da República, outro foi Prefeito da ca- pital, um último foi Prefeito e Deputado Estadual. Cabe grifar também, como pertencentes ao "clã dos Neivas” (COUTINHO, 2007, p. 169) José Neiva de Sousa, que se elegeu Deputado Federal em duas ocasiões e Senador em uma, e José Guimarães Neiva Moreira, que chegou à Assembléia Legislativa em uma vez e à Câmara dos Deputados em sete oportunidades.

O pai de Jaime Tavares Neiva de Santana, Pedro Neiva de Santana, formou-se em Medicina no Rio de Janeiro. A partir da década de 1930 radicou-se em São Luís, trabalhou no Gabinete de Identificação e no Gabinete Médico-Legal da Polícia Civil e foi nomeado Prefeito da capital pelo Interventor Paulo Ramos para o período 1937-1945. Desse modo, na seqüência, foi catedrático de Medicina Legal na Faculdade de Direito de São Luís e de Sociologia na Faculdade de Filosofia de São Luís e da Faculdade de Ciências Médicas do Maranhão. Em 1966 voltou a ocupar um cargo público, assumindo a Secretaria de Planejamento do então Governador José Sarney; logo em seguida foi o primeiro Reitor da Fundação Universidade do Maranhão (a atual Universidade Federal do Maranhão (UFMA)); por fim, foi Governador do Estado entre 1971 e 1974. Antes de morrer, foi eleito membro da Academia Maranhense de Letras. Segundo Nunes (2000, p. 332), "os cargos e postos referidos ao campo de poder viabilizam o acesso às posições consagradas no domínio das relações intelectuais”. Em outras palavras, “ele faz uso de sua consagração no campo de poder para alçar posições de consagração no campo intelectual” (idem, p. 344).

O imbricamento entre os domínios político e intelectual também está presente na justificação feito pelo seu filho para o destaque público alcançado pelo pai. A ele junta-se o conteúdo moral que busca ser associado à "imagem", mediante expressões como "homem culto", "sujeito bem informado", "formador de opinião", "homem de credibilidade", "cidadão acima de qualquer suspeita” etc. (SANTANA, 2006).

Seu filho, o ex-Deputado Federal Jaime de Santana, é economista formado na Faculdade Cândido Mendes, no Rio de Janeiro. Em 1968 assumiu a Secretaria Municipal da Fazenda em São Luís (aos 25 anos), após um período como assessor do pai na Secretaria Estadual da Fazenda do Maranhão. A partir de 1971 passou a acumular a Chefia da Casa Civil do Governo do Estado e a 
Secretaria Estadual da Fazenda, quando seu pai ocupava o cargo de Governador. Durante a gestão do sucessor de seu pai, Osvaldo Nunes Freire, trabalhou como Diretor da Companhia de Águas e Esgotos do Maranhão (Caema). No início da década de 1980, após mais de dez anos ocupando cargos públicos de primeiro escalão, concorreu pela primeira vez à deputação federal, com sucesso, pelo Partido Democrático Social (PDS). Em 1985 concorreu à Prefeitura de São Luís pelo Partido da Frente Liberal (PFL), com o apoio do então Presidente da República, José Sarney. Reelegeu-se Deputado Federal em 1986 pelo PMDB e em 1990 e 1994 pelo Partido da Social-Democracia Brasileira (PSDB). Nos últimos anos atuou como assessor especial do Governador do Estado do Maranhão.

Sua auto-apresentação como "político" e as definições de política mobilizadas são calcadas em noções como "vocação" e "arte”, associadas às habilidades "em formular, articular e operar" e "ser intelectualmente sério". A forma de conceber a política e de descrever a atuação dos demais membros da "família” realça o “desinteresse”, as competências compartilhadas por círculos restritos de sociabilidades e as qualidades intelectuais consideradas raras (idem).

\section{III.2. Imigração, ascensão social e especializa-} ção política

No que diz respeito ao segundo padrão identificado, ele compreende os "descendentes" de "famílias” que se estabeleceram socialmente nas décadas de 1930 a 1950 e o pai do primeiro político comumente se dedicava ao comércio, muitas vezes fazendo intermediação de "regiões" de "colônias de imigrantes”. Muitas dessas famílias estiveram ligadas às dinâmicas de imigração do século XIX e início do século XX e seus membros ascenderam e tornaram-se prósperos comerciantes e empresários. O ingresso da “família” na competição eleitoral ocorreu, então, a partir dos anos 1930 com forte incremento no período posterior à democratização de 1945. A grande maioria dos políticos é portadora de títulos superiores semelhantes àqueles conquistados pelos "descendentes” de "grupos familiares” estabelecidos há mais tempo. Outro fator comum é a combinação da ocupação de cargos municipais (prefeituras e vereança) e estaduais (deputação estadual ou federal, secretarias etc.) por diferentes membros das “famílias”. Essa divisão do trabalho político faci- lita tanto a manutenção de redutos (em geral onde se encontra a "colônia de imigrantes" de que são originários) como a afirmação estadual junto às máquinas e facções partidárias que disputam a hegemonia no cenário regional.

Em que pese a existência dessas semelhanças, uma série de aspectos distingue os casos examinados. No Rio Grande do Sul o ingresso na carreira eletiva ocorreu majoritariamente por meio de cargos locais (com destaque para a vereança); no Maranhão, pela deputação estadual ou federal e, eventualmente, pela Prefeitura (muito raramente pela vereança). No primeiro estado há maior afirmação eleitoral local baseada no prestígio conquistado como comerciantes e empresários e uma ascensão gradativa às posições eletivas e partidárias centrais no estado. No segundo estado, há igualmente a obtenção de notoriedade advinda do sucesso empresarial, porém essa notoriedade proporciona a fixação na capital e a cooptação para o exercício de cargos políticos, para a direção das máquinas políticas estaduais e para as candidaturas. No que se refere aos elementos ligados à imigração, cabe ressaltar a maior diversificação étnica no Rio Grande do Sul (alemães, italianos, sírios, libaneses, poloneses etc.) e o uso muito mais direto e explícito dessa identificação como recurso de mobilização eleitoral, ao passo que, no Maranhão, a identificação com imigrantes restringe-se a segmentos de "descendentes de libaneses” que constroem suas bases eleitorais via alianças políticas e matrimoniais no interior das máquinas partidárias e do círculo de "famílias" que as controlam. Finalmente, deve-se grifar a maior diversificação dos investimentos escolares no Rio Grande do Sul, que ocorre por meio de instituições públicas situadas na capital (como as "famílias tradicionais”), por instituições privadas na capital (sobretudo a Pontifícia Universidade Católica do Rio Grande do Sul (PUC-RS)) e por instituições no interior, públicas ou privadas (as chamadas “instituições comunitárias”). No Maranhão tais segmentos ascendentes necessitaram freqüentar instituições públicas situadas na capital ou em centros maiores, configurando maior concentração e seleção social na formação da "elite política” estadual.

A tônica na celebração da "origem familiar" entre os políticos que pertencem a "famílias" que se afirmaram mais recentemente recai na descrição das condições de origem adversas, sobretudo 
entre "imigrantes", e na excepcionalidade do trajeto do grupo familiar. O contraste entre o ponto de partida (obstáculos, dificuldades, discriminação) e o itinerário de "sucesso" em termos de ascensão social é grifado nos relatos. Nas formas de definição do exercício da atividade política esses agentes acionam qualidades naturalizadas que são buscadas exatamente nas biografias individuais e coletivas bem-sucedidas e ascendentes; apresentam-se como detentores de uma "vocação" para o "empreendedorismo" e para o "trabalho comunitário". Para tanto, utilizam-se de atributos que acreditam serem inatos como "capacidade de trabalho”, “capacidade de comunicação”, “audácia”, "vivência empresarial” etc. É interessante que os trunfos e as "habilidades" construídas sobre condicionantes específicos de afirmação social e econômica acabam constituindo-se "qualidades" tidas como próprias dos "alemães”, dos "italianos", dos "sírios", dos "libaneses" e/ou de determinadas "famílias de políticos". Sendo assim, as exceções (os casos excepcionais de ascensão) estabelecem a "regra” e prescrevem condutas modelares na política.

Aproximam-se desse padrão os casos de José Otávio, Pedro e Otávio Germano no Rio Grande do Sul e os de Joaquim e Nagib Haickel no Maranhão.

O atual Deputado Federal José Otávio Germano é neto de um casal de sírios. Seu avô, Taufik Germano, foi mascate, depois comerciante e, finalmente, empresário; foi um imigrante que, segundo seu filho, "veio da Síria em 1914 [...] e teve uma vida de luta, de muita dificuldade", ascendeu socialmente em Cachoeira do Sul e teria tido uma “intensa atuação comunitária” (GERMANO, 2001). Além disso, Taufik tinha fortes ligações com as lideranças então dominantes na política gaúcha. Soma-se a isso o seu papel de intermediário comercial entre os diferentes distritos na "região" e entre as zonas rural e urbana. Tal atividade seria responsável pelas influência e projeção que obteve; como destaca José Otávio Germano, "cresceu o negócio dele [...] e então ele começou a ter influência em toda a região" (GERMANO, 2002).

O ex-Deputado Federal e advogado formado na UFRGS Otávio Germano é o terceiro filho de Taufik Germano. Atuou no movimento estudantil e foi Presidente Estadual da ala moça do PSD. Casou-se com uma descendente de imigrantes sírios, ligados ao comércio e vinculados por laços de parentesco à “família Germano”. Otávio Germano iniciou sua carreira como Vereador (aos 28 anos); depois de exercer a vereança entre 1952 e 1962 e de perder uma eleição para a Assembléia Legislativa em 1958, elegeu-se Deputado Estadual três vezes consecutivas. Nesse período (19631974) foi Secretário de Estado e Presidente da Assembléia Legislativa. Em 1974 chegou à Câmara dos Deputados e, em 1978, ao cargo de viceGovernador (eleito pela Assembléia Legislativa). Em 1982 perdeu as prévias no interior do seu partido para a escolha do candidato a Governador. Ocupou a Presidência da Caixa Econômica Estadual entre 1983 e 1985; em 1986 não obteve sucesso na tentativa de voltar à Câmara dos Deputados e foi posteriormente convidado a ocupar um cargo em uma indústria estatal (Aços Finos Piratini).

Seu irmão, o médico veterinário formado na UFRGS e advogado formado na Universidade de Cruz Alta (Unicruz) Pedro Germano elegeu-se Vereador em Cachoeira do Sul (aos 32 anos). Depois de ocupar a Presidência da Câmara de Vereadores, concorreu a Prefeito por uma das sublegendas da Arena, em 1968, sem sucesso. Foi então convidado a assumir a Chefia de Gabinete, entre 1971 e 1972, da Secretaria do Interior e da Justiça, dirigida pelo irmão. Em 1972 Pedro Germano elegeu-se Prefeito de Cachoeira do Sul com base na forte influência do trabalho de "atendimento ao município” exercido na Secretaria. Em 1978 e em 1982 elegeu-se Deputado Federal.

O irmão mais novo de Otávio Germano, Geraldo Germano, foi Vereador em Cachoeira e Presidente da Câmara de Vereadores. Em 1974 concorreu a Deputado Estadual em “dobradinha” com Octávio Germano e elegeu-se. Em 1978 e em 1982 conseguiu a reeleição, dessa vez em "parceria" com o outro irmão, Pedro Germano, que também foi exitoso nas duas eleições.

Na atual geração, o principal protagonista político é o filho de Otávio Germano, José Otávio Germano. Advogado formado na PUC-RS, onde atuou no movimento estudantil, e ex-Presidente do "Movimento Jovem do PDS", estabeleceu-se profissionalmente em Cachoeira do Sul como advogado e professor universitário, após ter sido Chefe de Gabinete do pai na Presidência da Caixa Econômica Estadual. Em 1988 elegeu-se Vereador (aos 26 anos) e em 1990 chegou à Assem- 
bléia Legislativa. Ocupou dois mandatos (19911998) e a Presidência do parlamento gaúcho. Foi ainda Secretário Estadual dos Transportes do Rio Grande do Sul entre 1995 e 1998; em 1998 concorreu a vice-Governador, sem êxito. Ocupou o Ministério Adjunto dos Esportes durante o último mandato do Presidente Fernando Henrique Cardoso (1999-2002) e elegeu-se Deputado Federal em 2002; em 2003 passou a dirigir a Secretaria Estadual de Justiça e Segurança Pública e reelegeu-se Deputado Federal em 2006.

Paralelamente ao exercício por parte de José Otávio Germano dessa liderança estadual, outro membro da "família" desempenhou atribuições mais "locais". Trata-se do empresário Taufik Germano Neto, conhecido como "Pipa” Germano, primo de José Otávio Germano. Ele elegeu-se Vereador de Cachoeira do Sul em 1992 e Prefeito da mesma cidade em 1996 e 2000, além de ter sido o Presidente da Federação dos Municípios do Estado do Rio Grande do Sul (Famurs).

"Os Germanos”, ao longo de duas gerações, conseguiram articular as posições locais e estaduais e maximizar sua notoriedade e hegemonia locais como trunfo nas disputas e ascensão política, assim como mantiveram seus redutos com o “atendimento" e a intermediação possibilitada pela ocupação de mandatos de deputados e a ocupação de secretarias de estado.

Os ex-deputados federais pelo Maranhão Joaquim Nagib Haickel e Nagib Haickel são descendentes de libaneses. Entre os antepassados que imigraram para o Brasil, parte da "família" fixouse no Rio Grande do Sul e parte no Maranhão. Nagib Haickel é filho de um casal de primos libaneses e o pai era comerciante. Os ascendentes chegaram ao estado na primeira década do século XX e radicaram-se em Pindaré Mirim. Nesse município, segundo um dos descendentes da "família”, constituiu-se "uma espécie de fronteira de desenvolvimento e os imigrantes iam para o pátio dessas fábricas vender: vender roupas, vender mantimentos e utensílios; foi nessa enxurrada que meus avós vieram então se estabelecer em Pindaré Mirim e lá tem uma grande uma grande colônia libanesa” (HAICKEL, 2006).

O irmão mais velho de Nagib Haickel foi o primeiro a ingressar na arena eletiva. José Antônio Haickel, comerciante e proprietário de uma usina de arroz, aproximou-se de José Sarney, então can- didato das "oposições coligadas" ao Governo do Estado, e elegeu-se Prefeito de Pindaré Mirim pela primeira vez em 1965. Constituiu uma sólida liderança local que possibilitou que se elegesse duas outras vezes Prefeito do Município.

Um ano após a eleição do irmão, Nagib Haickel concorreu pela primeira vez à deputação estadual e elegeu-se. Já estava radicado em São Luís, onde trabalhou inicialmente com uma "família de libaneses” também atuantes politicamente ("os Abouds"). Posteriormente, "teve sucesso na vida empresarial [...]; enveredou mais no comércio mesmo de atacado de material de construção, de gêneros alimentícios” (idem). Tinha como principal "reduto eleitoral” a cidade de Pindaré Mirim e municípios próximos. Segundo depoimento do seu filho, os sucessos empresarial e político decorriam de "qualidades inatas" como ser "comunicativo”, "trabalhador”, "audaz” e "homem de visão" (idem). Casou-se com uma filha de pequenos comerciantes de origem portuguesa.

Nagib Haickel elegeu-se, então, Deputado Estadual três vezes consecutivas (1966,1970 e 1978). Em 1978 e 1982 elegeu-se Deputado Federal; nesta última eleição fez “dobradinha” com o filho, o então estudante de Direito da UFMA, Joaquim Nagib Haickel, contribuindo decisivamente para a primeira eleição deste como Deputado Estadual. Em 1986 decidiu lançar o filho candidato à Assembléia Nacional Constituinte, com sucesso, e concorreu novamente à deputação estadual. Sofreu a primeira derrota em virtude da divisão da base com outros candidatos diretamente vinculados a ele. Entre 1987 e 1988 tornou-se o primeiro administrador do município recém-criado, chamado Zé Doca. Em 1990 voltou a concorrer a Deputado Estadual, com sucesso, e morreu na Presidência da Assembléia Legislativa.

Seu filho, Joaquim Nagib Haickel, ingressou na carreira eletiva como Deputado Estadual (aos 22 anos) com base no prestígio acumulado pelo pai (ao longo de três mandatos de Deputado Estadual e um de Deputado Federal) e do tio (devido às três gestões na Prefeitura de Pindaré Mirim). Antes de concorrer pela primeira vez a um cargo eletivo foi Chefe do Gabinete do Governador João Castelo (aos 20 anos). Sua primeira eleição foi conquistada basicamente com votos concentrados na “região de Pindaré Mirim”. Joaquim Haickel concluiu o curso de Direito na UFMA e participou de movimentações culturais como poeta e escri- 
tor durante o mandato. Em 1986 substituiu o pai como candidato a Deputado Federal - segundo sua versão, devido à sua formação jurídica, mais condizente com o papel de constituinte. Durante ainda o mandato investiu na atividade empresarial como proprietário de uma concessionária de automóveis, de uma editora e de uma cadeia de rádios e televisões em sociedade com Fernando Sarney (filho de José Sarney).

Em 1990 não concorreu à reeleição. O esforço familiar concentrou-se no retorno de Nagib Haickel à Assembléia Legislativa. Foi então convidado a ocupar o cargo de Subsecretário de Ações Políticas no governo Édison Lobão, responsabilizando-se diretamente pelo atendimento aos pleitos dos prefeitos do interior. Posteriormente ocupou a Subsecretaria de Educação. Entre 1995 e 1998 investiu exclusivamente nas suas empresas, incrementando mesmo a sociedade com Fernando Sarney e, em 1998, concorreu a Deputado Estadual. A passagem pelo poder Executivo e o "sucesso empresarial" conquistado permitiram uma reentrada na arena eletiva como Deputado Estadual e o início de uma nova carreira calcada nos feitos pessoais, sem se desvincular da "herança política”. Assim, reelegeu-se três vezes consecutivas Deputado Estadual (1998, 2002 e 2006).

III.3. “Origem humilde”, militância e especialização política

O terceiro padrão identificado contempla um conjunto de deputados que se aproximam pela "origem humilde" reivindicada nas auto-apresentações. Seus "antepassados” pertenceram às camadas mais baixas da população e a ascensão social sucedeu ao ingresso na competição eleitoral. O pai do deputado ou do primeiro político na "família” exerceu profissões como de pequeno agricultor, pequeno comerciante, empregado de grandes propriedades rurais, pescador, metalúrgico, pedreiro etc. A estréia dos agentes ou dos seus "familiares" na disputa por cargos eletivos aconteceu a partir do final dos anos 1950, intensificando-se nas décadas mais recentes. Predominam os deputados com título superior. Raramente os casos associados a esse padrão inauguraram sua atuação como ocupantes de cargos eletivos como Deputado Federal. Majoritariamente eles estrearam como vereadores (mais freqüentemente no Rio Grande do Sul) ou deputados estaduais (situação mais freqüente no Maranhão). A relevância da passagem por instituições privadas na capital e privadas e públicas no interior entre os deputados gaúchos, em contraposição à centralidade das instituições públicas na capital para os deputados maranhenses, é o principal elemento de diferenciação regional.

Por fim, entre aqueles políticos que se aproximam do terceiro padrão, os relatos concernentes às "origens familiares" centram-se na caracterização da "precariedade", da "humildade", da "carência" que marcaram os "antepassados" do primeiro político. São enfatizados os aspectos que os diferenciam dos demais políticos de origem "tradicional” ou que são originários de "famílias" que ascenderam economicamente, como a inexistência de "tradição política familiar", as dificuldades de acesso aos títulos escolares e a "necessidade de conciliar trabalho e estudo". Os entrevistados, nas estratégias de auto-apresentação e para explicar a ascensão política a partir da "origem humilde”, utilizam termos para definir a sua "vocação política" e a de seus familiares como "obstinação", "superação", "missão" e até "predestinação”. A idéia de excepcionalidade, assim, apóia-se na raridade do perfil no interior da "classe política", na baixa probabilidade de êxito sob tais condições e no exemplo de "superação".

O ex-Deputado Federal pelo Rio Grande do Sul Wilson Branco e o atual Deputado Federal pelo Maranhão Domingos Dutra são casos exemplares do padrão descrito.

Originário de uma "família de pescadores", o ex-Deputado Federal Wilson Branco é considerado o "fundador" de uma "família de políticos" do Rio Grande do Sul, como salienta o depoimento do seu filho: "a gente pode conversar sobre como começou a história do pai, porque a política, uma coisa, a política não tava no sangue, o pai iniciou [...]” (BRANCO, 2003). Wilson Branco estudou até a quinta série do Ensino Fundamental no colégio Sipriano Porto Alegre em Rio Grande e concluiu o curso técnico de mecânica marítima do Serviço Nacional de Aprendizagem Industrial (Senai). Sua baixa escolaridade costuma ser contrabalançada pela ênfase no autodidatismo e valorizada como símbolo de proximidade e associação com o seu eleitorado. Aliou a atuação no futebol amador (inicialmente como jogador, depois como dirigente e técnico e finalmente como comentarista de rádio) à liderança política entre os pescadores, como Presidente, a partir de 1985, da Colônia de Pescadores Z1 e como Presidente 
da Federação dos Pescadores do Estado do Rio Grande do Sul. Soma-se a isso uma aliança matrimonial com a filha de um pequeno comerciante do distrito de origem.

O “acesso" que os eleitores desfrutavam junto ao homem político e a ausência de barreiras sociais entre ele e aqueles que o procuravam com "demandas" e "solicitações” de atendimentos são ingredientes importantes da sua afirmação política. Acrescenta-se a isso uma série de atos realizados e divulgados no sentido de fixar a imagem de um líder com componentes de heroísmo: "coragem" e "iniciativa” para posicionar-se em situações que envolviam conflitos e relações desiguais de poder firmaram sua condição de mediador local e assinalaram o acesso assim conquistado junto aos centros local e nacional da vida política. A união desses componentes em uma trajetória política excepcional devido a uma posição social de origem incomum para os cargos ocupados permitiu a sua auto-apresentação como alguém "iluminado", com elementos que faziam alusão a uma "predestinação" (idem) igualmente presente no trabalho de produção do seu carisma.

Assim, Wilson Branco tem seu carisma fundamentado em atributos pessoais, em feitos heróicos ligados à sua vida privada (a superação de obstáculos de origem) e em suas tomadas de posição públicas, bem como na exaltação de determinadas carências sociais. Logo, seria detentor de qualidades individuais (facilidade de comunicação, domínio de códigos populares e autodidatismo) singulares e originadas do desapossamento social, político e cultural: isso contribuiu para a sua "imagem política".

Wilson Branco percorreu um itinerário de cargos eletivos que se iniciou com a sua eleição como Vereador de Rio Grande em 1992 pelo PMDB; em 1994 concorreu a Deputado Federal pelo mesmo partido, ficando em uma das suplências. Assumiu em 1995 e dedicou-se à "defesa do setor primário, sobretudo pesqueiro” (idem). Em 1996 elegeu-se Prefeito de Rio Grande e morreu em 2000 em plena campanha de reeleição, quando era o líder das pesquisas e grande favorito.

Assim, o então candidato a Vereador, Fábio Branco, e o Secretário Municipal, Janir Branco, respectivamente sobrinho e filho do candidato líder das pesquisas e seus principais colaboradores, impuseram-se como "continuadores" do seu “trabalho”. Sucessor do tio na Presidência da colônia de pescadores, assessor na Câmara de Vereadores e no Congresso Nacional e supervisor da Secretaria Municipal de Agricultura durante o mandato de Wilson Branco na Prefeitura, Fábio Branco foi escolhido candidato a Prefeito de Rio Grande. O "acompanhamento do trabalha político" de Wilson Branco é sempre realçado como o grande trunfo dos primos e como justificativa para a sucessão das posições políticas. Ambos teriam participado das atividades na colônia de pescadores, além de assessorar no mandato na Câmara de Vereadores e coordenar o escritório - cuja sede era na própria colônia de pescadores - de atendimento do mandato de Deputado. Finalmente, contribuíram com a ocupação de cargos no governo municipal (gestão 1996-2000).

Fábio Branco elegeu-se e a gestão municipal passou a ser o novo "teste" dos "jovens políticos”. Fábio Branco contou, na administração municipal, com o auxílio direto de seu primo, o então estudante de Engenharia da Fundação Universidade Federal do Rio Grande (FURG) Janir Branco, escolhido para ocupar o cargo de Secretário-Geral de Governo, além de outros colaboradores da equipe de Wilson Branco. Nesse processo, a candidatura de Janir Branco à deputação estadual constituiu mais uma "aposta" na sucessão política e um movimento de sedimentação da liderança. Janir Branco elegeu-se Deputado Estadual e passou a cursar Direito nas Faculdades RioGrandenses (FARGS). Sua eleição foi apresentada como "a realização do sonho do pai"; expressões como "predestinação", "missão”, "desafio", "destino" etc. são acionadas na apresentação pessoal e familiar (idem).

Atualmente Janir Branco ocupa a Prefeitura de Rio Grande, em virtude da cassação do seu primo, Fábio Branco, durante o pleito de 2004. Fábio Branco concorria à reeleição e foi substituído por Janir Branco duas semanas antes da eleição. Mesmo com o período exíguo de campanha, o principal posto político local permaneceu sob o controle da "família de políticos" com aproximadamente $70 \%$ dos votos locais.

O atual Deputado Federal Domingos Dutra é descendente de uma "família" de "trabalhadores rurais" em uma pequena localidade do interior do Maranhão, Saco das Almas, hoje município Buriti de Inácia Vaz, que, segundo ele, "recentemente passou a ser a denominado Quilombo”. Seu pai 
foi "vaqueiro" e "lavrador” e a mãe, "quebradeira de coco", "doméstica” e "lavradora” (DUTRA, 2006). Teve 20 irmãos por parte de mãe e 29 por parte de pai, dos quais apenas uma irmã chegou à universidade.

Seu deslocamento para capital deu-se aos 11 anos de idade. Alfabetizou-se depois de adulto. $\mathrm{Na}$ adolescência atuou em um grupo de teatro da "periferia” ligado à Igreja Católica e chamado "Grita”. Após "servir no Exército”, foi empacotador de supermercado e integrou um grupo de teatro da Universidade Federal do Maranhão denominado "Gangorra". Teria combinado a influência dos colegas do grupo de teatro e a realização de um curso pré-vestibular para ingressar no curso de Direito da UFMA: "com a economia de ir a pé todos os dias, eu paguei cursinho. [...] E [foi] na universidade que eu vim [a] descobrir o movimento político, naquele tempo já era... já [es]tava[m] surgindo as greves do ABC ${ }^{15 ”}$ (idem).

Durante a graduação foi professor de História em colégios particulares; na universidade participou de "grupos" no movimento estudantil cujos integrantes formaram as principais "agremiações partidárias de esquerda" do estado (notadamente o Partido dos Trabalhadores (PT)). Profissionalmente atuou como advogado da Comissão Pastoral da Terra, da Sociedade Maranhense dos Direitos Humanos, da Cáritas Brasileira, de sindicatos rurais e urbanos e em defesa dos "quilombolas".

Concorreu a Vereador de São Luís em 1982 e 1988 e não obteve êxito. Ainda na década de 1980 foi um dos principais líderes do PT e de uma tendência denominada "PT de Aço", notabilizada pela atuação junto aos movimentos de trabalhadores rurais. Ocupou vários cargos de direção nos diretórios municipal e estadual. Alcançou o primeiro cargo eletivo como Deputado Estadual em 1990 (aos 34 anos); em 1994 elegeu-se Deputado Federal e, em 1996, vice-Prefeito de São Luís. Em 2002 retornou ao poder Legislativo estadual e, em 2006, reconquistou o mandato de Deputa-

$\overline{15}$ A região chamada de "ABCD paulista” é composta pelas seguintes cidades da Região Metropolitana de São Paulo: Santo André, São Bernardo, São Caetano e Diadema. Elas concentram indústrias automotivas e, no final dos anos 1970, foram palco de grandes greves de trabalhadores; essas greves - as primeiras que ocorriam em cerca de dez anos, durante o regime militar - marcaram o surgimento do "novo sindicalismo" (nota do revisor). do Federal. É o atual Presidente do Diretório Regional do PT. Um dos seus filhos prepara uma candidatura à vereança em um pequeno município localizado na "Ilha de São Luís" (faz limite com a capital do estado por meio de um bairro no qual a "família” habitou durante décadas e sempre foi um importante "reduto eleitoral" de Domingos Dutra).

Sua auto-apresentação apóia-se em qualidades como a de ser portador de "um discurso muito forte baseado no real e não no livro", fazendo uso de expressões alusivas à sua "origem rural e humilde", a um sentido de "missão" que não permite "omissão diante das injustiças", além da "identidade partidária” e da "coerência partidária”. Tais elementos possibilitariam, segundo ele, que, apesar de não possuir "tradição política na família", ter optado por "canalizar a ação pro segmento mais pobre". A origem da escolha seria "Uma coisa da natureza, vem de dentro. E por vir de dentro é que faz com que a gente resista a todas as dificuldades [...]. E acabou levando, aprofundando essa opção de ser militante. Então, nós nos tornamos militantes e tem horas que nós nos tornamos militares” (idem).

\section{III.4. Desqualificações, osmoses e interpene-tra-} ções

Além de utilizarem suas origens e recursos como critérios de legitimação e de definição das suas atuações políticas, os agentes investem também na desqualificação ou estigmatização dos adversários. Por um lado, a aproximação com o "padrão mais tradicional” contribui para que os agentes identifiquem nos novos perfis que ingressam na arena eletiva causas da "degeneração da política”, do "espírito público” etc. que seriam compatíveis com as suas qualidades ou atributos. Entre os principais repertórios de "desqualificação" encontra-se a crítica à "profissionalização da política”, aо "carreirismo", à busca da política como “subsistência” etc.

Por outro lado, aqueles que buscam afirmarse no jogo político assinalam a importância para a "democracia" da "renovação" e da presença de novos segmentos sociais nos postos políticos, associando os agentes ligados a "grupos familiares” estabelecidos, social e politicamente há mais tempo a traços de "conservadorismo", "atraso" e "estagnação". Como elemento fundamental de desqualificação, esses agentes lançam mão da associação entre "famílias tradicionais" e "oligarqui- 
as”, “aristocratismo”, “dinastias”, “nepotismo”, "clientelismo" etc.

É necessário realçar que tais “denúncias” não significam que os seus promotores abdiquem de longos períodos de cargos políticos (no primeiro caso) ou de promover a sucessão política no interior da "família” (no segundo caso). É importante salientar ainda que, embora haja uma correlação entre perfis e estratégias que visam a desacreditar os concorrentes, tais investimentos de desqualificação são relativos às relações que estão sendo enunciadas. As designações de "político tradicional" e "família tradicional”, por exemplo, podem ser usadas para classificar qualquer político ou grupo familiar estabelecido há mais tempo que aquele que faz uso da expressão, buscando afirmar-se. Do mesmo modo, a crítica à “profissionalização na política” é sempre mais contundente em entrevistados que estão no início da carreira e é dirigida aos políticos mais experientes.

Contudo, as interações não se resumem às oposições ou às rivalidades. Da mesma forma há alianças, osmoses e interpenetrações. É significativo o número de casamentos entre descendentes de "famílias" com perfis diferenciados ("tradicional", "ascendente" e de "origem humilde") formando "famílias de políticos" ainda com melhores resultados eleitorais e com uma superfície de relações e de bases sociais ainda mais variada e eficaz. Além disso, as lógicas de concorrência levaram à produção de meios, de tecnologias e de repertórios comuns e próprios ao espaço político. $\mathrm{O}$ enfraquecimento das redes de dependentes e clientes administradas pelas "elites tradicionais" fez que as mesmas investissem em máquinas partidárias (cooptando e integrando novos segmentos sociais sob a sua influência), em meios de comunicação, em cabos eleitorais remunerados, em discursos inovadores etc. Os mecanismos já sedimentados de relação candidato-eleitor levaram as novas camadas sociais a utilizarem práticas baseadas na reciprocidade, no dom e na honra, possibilitadas, por seu turno, pela complexificação do espaço da "representação política" (organizações, instituições etc.).

\section{CONSIDERAÇÕES FINAIS}

O conjunto de dados apresentados ao longo do texto revela alguns aspectos do processo de especialização na política em curso ao longo do território brasileiro, das variações regionais da elite política e a diversificação social no recrutamento dos parlamentares ocorrido nos últimos 60 anos no país.

No primeiro momento, mediante o exame de duas configurações regionais - que estão entre as consideradas mais distintas -, foi possível demonstrar elementos comuns de profissionalização política (ingresso precoce, longos períodos de ocupação de cargos eletivos e políticos etc.) e de monopolização de postos políticos por agentes e “famílias". No segundo momento, destacou-se, com pesos e modalidades distintos, o ingresso de novos segmentos sociais na arena política, novos trunfos de atuação e estratégias de legitimação ímpares. A despeito dessas constatações, os mecanismos de ingresso, os condicionantes sociais de atuação política e as formas de ascensão ou continuidade na carreira política revelaram-se contrastantes.

No caso do Rio Grande do Sul, predominam itinerários ascendentes a partir de cargos eletivos (com destaque para a vereança), profissionais ligadas ao "saber humanístico", formação escolar de nível superior capilarizada pelo território por meio de instituições públicas e privadas e peso das posições conquistadas via processos eleitorais nos trajetos políticos. No Maranhão, prevalecem percursos iniciados via cargos de primeiro escalão e/ou cargos eletivos centrais (especialmente a deputação federal), salientam-se as ocupações associadas ao "saber técnico" e a formação em instituições públicas situadas na capital ou em centros maiores, além da importância dos cargos públicos como instrumento de cooptação e como trampolins nas carreiras.

A concorrência, as osmoses e as interpenetrações entre agentes com perfis distintos que são resultantes e propulsoras de transformações da estrutura social e política de cada configuração foram modelando recursos e trunfos tidos como legítimos de serem usados na disputa eleitoral. Do mesmo modo, é viável extrapolar tais considerações para refletir a respeito da composição da "elite política brasileira” e das suas práticas como resultante de uma configuração de forças regionais e sociais que interagem, mesclamse, fundem-se e forjam "modelos de comportamentos”, instituições compósitas (partidos, legislativos etc.) e linguagens de exercício da atividade política. 
Igor G. Grill (igorgrill@terra.com.br) é Doutor em Ciência Política pela Universidade Federal do Rio Grande do Sul (UFRGS) e Professor do Departamento de Sociologia e Antropologia e do Programa de Pós-Graduação em Ciência Sociais da Universidade Federal do Maranhão (UFMA).

\section{REFERÊNCIAS BIBLIOGRÁFICAS}

ABREU, A.; BELOCH, I.; LATTMANWELTMAN, F. \& LAMARÃO, S. 2001. Dicionário histórico-biográfico brasileiro pós-30. $2^{\mathrm{a}}$ ed. Rio de Janeiro : FGV.

BORGES, A. S. 2004. Conexão eleitoral e atuação parlamentar. Rio de Janeiro. Tese (Doutorado em Ciência Política). Instituto Universitário de Pesquisas do Rio de Janeiro.

BRANCO, J. 2003. Entrevista com Igor Grill. Porto Alegre, 16.maio.

BUZAR, B. 1998. O vitorinsimo. Lutas políticas no Maranhão de 1945 a 1965. São Luís : Lithograf.

2001. Vitorinistas e oposicionistas. São Luís : Lithograf.

CÁNEPA, M. 1999. Partidos e representação política. Porto Alegre. Tese (Doutorado em Ciência Política). Universidade Federal do Rio Grande do Sul.

CORADINI, O. L. 1998a. Elites culturais e concepções de política no Rio Grande do Sul entre as décadas de vinte e sessenta. Porto Alegre. Relatório de pesquisa. Universidade Federal do Rio Grande do Sul.

1998b. Origens sociais, mediação e processo eleitoral num município de imigração italiana. In : PALMEIRA, M. \& BARREIRA, I. (orgs.). Candidatos e candidaturas. São Paulo: Annablume.

2001. Em nome de quem? Recursos sociais no recrutamento de elites políticas. Rio de Janeiro : Relumé-Dumará.

2007. Engajamento associativo-sindical e recrutamento de elites políticas : tendências recentes no Brasil. Revista Sociologia Política, Curitiba, n. 28, p. 181-203. Disponível em : http://www.scielo.br/pdf/rsocp/n28/ a12n28.pdf. Acesso em : 15.mar.2008.

COSTA, W. C. 2006. Sob o signo da morte. São Luís : UFMA.
COUTINHO, M. A. 2007. Presença do Maranhão na Câmara dos Deputados : notas biobibliográficas. São Luís : Legenda.

DOGAN, M. 1999. Les professions propices à la carrière politique. In : OFFERLÉ, M. (org.). La profession politique. Paris : Belin.

DUTRA, D. 2006. Entrevista com Igor Grill. São Luís, 14.dez.

ELIAS, N. 1999. Introdução à Sociologia. Lisboa : ed. 70.

2001. Estudos sobre a gênese da profissão naval. Mana, Rio de Janeiro, v. 7, n. 1, p. 89-116. Disponível em : http://www.scielo.br/ pdf/mana/v7n1/a05v07n1.pdf. Acesso em : 15.mar.2008.

FAUSTO, B. 1995. Imigração e participação política na Primeira República. In : __ (org.). Imigração e política em São Paulo. São Paulo : Sumaré.

FERNANDES, R. 1980. José Martins da Cruz Jobim : um fundador da Academia Nacional de Medicina. Revista do Instituto Histórico e Geográfico Brasileiro, Rio de Janeiro, v. 327, p. 45-55.

GARRAUD, P. 1989. Profession homme politique. Paris : Harmattan.

GAXIE, D. 1980. Les logiques du recrutement politique. Revue Française de Science Politique, Paris, v. 30, n. 1, p. 5-45. Disponível em : http://www.persee.fr/articleAsPDF/ rfsp_0035-2950_1980_num_30_1_393877/ a r t i c l e $-\mathrm{rfs}$ s -0035 . 2950_1980_num_30_1_393877.pdf. Acesso em : 15.mar.2008.

GERMANO, J. O. 2002. Entrevista com Igor Grill. Cachoeira do Sul (Rio Grande do Sul), 12.ago.

GERMANO, O. 2001. Entrevista com Igor Grill. Cachoeira do Sul (Rio Grande do Sul), 13.abr. 
GONÇALVES, M. F. C. 2000. A reinvenção do Maranhão dinástico. São Luís : UFMA.

2006. A invenção de uma Rainha de Espada : reatualizações e embaraços na dinâmica política do Maranhão dinástico. São Luís. Tese (Doutorado em Políticas Públicas). Universidade Federal do Maranhão.

GRILL, I. G. 2003. Parentesco, redes e partidos: as bases das heranças políticas no Rio Grande do Sul. Porto Alegre. Tese (Doutorado em Ciência Política). Universidade Federal do Rio Grande do Sul.

GRÜN, R. 1995. Os judeus na política paulista : identidade, anti-semitismo e cultura. In : FAUSTO, B. (org.). Imigração e política em São Paulo. São Paulo : Sumaré.

HAICKEL, J. 2006. Entrevista com Igor Grill. São Luís, 7.nov.

JOBIM NETO, W. 2001. Entrevista com Igor Grill. Porto Alegre, 11.jun.

MARENCO, A. 2000. Não se fazem mais oligarquias como antigamente. Porto Alegre. Tese (Doutorado em Ciência Política). Universidade Federal do Rio Grande do Sul.

MARENCO, A. \& SERNA, M. 2007. Por que carreiras políticas na esquerda e na direita não são iguais? Recrutamento legislativo em Brasil, Chile e Uruguai. Revista Brasileira de Ciências Sociais, São Paulo, v. 22, n. 64, p. 94113, jun. Disponível em : http://www.scielo.br/ pdf/rbcsoc/v22n64/a08v2264.pdf. Acesso em : 15.mar.2008.

MICELI, S. 1981. Carne e osso da elite política brasileira pós-30. In : FAUSTO, B. (org.). História geral da civilização brasileira. São Paulo : Difel.

NUNES, P. P. 2000. Medicina, poder e produção intelectual. São Luís : UFMA.

OFFERLÉ, M. 1996. Entrées en politique. Politix, Paris, n. 35, p. 3-5.

1999. Professions et profession politique. In : OFFERLÉ, M. (org.). La profession politique. Paris : Belin.

PHELIPPEAU, E. 1999. La fin des notables revisitée. In : OFFERLÉ, M. (org.). La profession politique. Paris : Belin.

2001. Sociogênese da profissão política. In : GARRIGOU, A. \& LACROIX, B. (orgs.). Norbert Elias. A política e a história. São Paulo : Perspectiva.

2002. L'invention de l'homme politique moderne. Paris : Bélin.

PINTO, C. R. 1986. Positivismo : um projeto político alternativo (RS : 1889-1930). Porto Alegre : UFRGS.

REIS, E. T. 2007. Contestação, engajamento e militantismo. Porto Alegre. Tese (Doutorado em Ciência Política). Universidade Federal do Rio Grande do Sul.

REIS, F. 2007. Grupos políticos e estrutura oligárquica no Maranhão. São Luís : s/n.

RODRIGUES, L. M. 2002. Partidos, ideologia e composição social. São Paulo : USP.

2006. Mudanças na classe política brasileira. São Paulo : Publifolha.

SAKURAI, C. 1995. A fase romântica da política : os primeiros deputados nikkeis no Brasil. In : FAUSTO, B. (org.). Imigração e política em São Paulo. São Paulo : Sumaré.

SANTANA, J. 2006. Entrevista com Igor Grill. São Luís, 28.nov.

SAWICKI, F. 1997. Les reseaux du Parti Socialiste. Paris : Belin

SEYFERTH, G. 1999. Etnicidade, política e ascensão social : um exemplo teutobrasileiro. Mana, Rio de Janeiro, v. 5, n. 2, p. 38-58. Disponível em : http://www.scielo.br/pdf/ mana/v5n2/v5n2a03.pdf. Acesso em : 15.mar.2008.

TRINDADE, H. \& NOLL, M. I. 1991. Rio Grande do Sul, partidos e eleições (1823-1990). Porto Alegre : UFRGS.

TRUZZI, O. 1995. Sírios e libaneses em São Paulo. In : FAUSTO, B. (org.). Imigração e política em São Paulo. São Paulo : Sumaré.

WILLEMEZ, L. 1999. La "République des avocats". In : OFFERLÉ, M. (org.). La profession politique. Paris : Belin.

Artigo modificado por solicitação do editor em (Abril/2009). 